\title{
Public Mass Modern Education, Religion, and Human Capital in Twentieth-Century Egypt
}

\author{
Mohamed Saleh \\ Toulouse School of Economics and the Institute for Advanced Study in Toulouse
}

\begin{abstract}
Mailing Address: Toulouse School of Economics, Manufacture des Tabacs, 21 Allée de Brienne, Building F, Office MF 524, Toulouse Cedex 6, F - 31015, FRANCE.

E-mail: mohamed.saleh@tse-fr.eu.
\end{abstract}

Acknowledgements: I thank Paul Rhode, the editor of the Journal of Economic History, and two anonymous referees for their excellent comments. I am grateful to my advisors, Dora Costa, Leah Boustan, and Jeffrey Nugent, for their support. I benefited from conversations with Ragui Assaad, Jean-Paul Azam, Eli Behrman, Naomi Lamoreaux, Stéphane Straub, and many colleagues at TSE and the IAST, and from presenting this article at UCLA, MESA (2010), International Committee for Historical Demography (2010), AALIMS (2013), Oxford Center for Islamic Studies, Namur, and LSE Economic History. I thank Norhan Muhab for her excellent research assistance and Marina Anis and Nardine Nabil for their data collection efforts. Support through EHA, USC, and the ANR-Labex IAST, is gratefully acknowledged. All errors are mine. 


\section{Public Mass Modern Education, Religion, and Human Capital in Twentieth-Century Egypt}

Public mass modern education was a major pillar of state-led development in the post-Colonial period. I examine the impact of Egypt's transformation in 1951-1953 of traditional elementary schools (kuttabs) into modern primary schools on the Christian-Muslim educational and occupational differentials, which were in favor of Christians. The reform allowed kuttabs' graduates, where Muslim students were over-represented, access to higher stages of education that were previously confined to primary schools' graduates. Exploiting the variation in exposure to the reform across cohorts and districts of birth among adult males in 1986, I find that the reform benefited Muslims but not Christians.

\section{Introduction}

What Europe is suffering from is the result of generalizing education among all levels of society... they have no chance of avoiding what happened [Europe's 1848 revolutions]. So if this is an example in front of us, our duty is simply to teach them how to read and write to a certain limit in order to encourage satisfactory work and not to spread education beyond that point.

Muhammad Ali Pasha, Ottoman Viceroy of Egypt (1805-1848), in a private letter to his son, Ibrahim Pasha (in Judith Cochran 1986, p. 6)

Education is like the water we drink and the air we breathe.

Taha Hussein, Egyptian liberal intellectual and Egypt's Minister of Education (1950-1952) The poor go to heaven, but can't they have a share on Earth too? They are willing to give up a share in heaven in exchange for a share on Earth.

Gamal Abdul-Nasser, President of Egypt (1956-1970) (Excerpt from a public speech) Public mass modern education was a major pillar of the state-led development model that was widely adopted throughout the developing world in the post-Colonial period. This was usually advocated by governments not only on the grounds of human capital accumulation and economic growth, but also on egalitarian grounds with the objective of reducing human capital inequality. Achieving these objectives 
entailed a certain challenge, however: How to unify the dichotomous educational system that was often inherited from the Colonial Era with its two components, (a) the pre-Colonial traditional schools that served the masses but provided little opportunity for educational or occupational advancement and (b) the Colonial modern schools that served the elites and were the gateway of university education and white-collar jobs? The unification process was particularly important in ethno-religiously diverse societies, where the Colonial educational system preserved, or even aggravated, inter-group human capital differentials, which were, at least partially, responsible for inter-group tensions.

But regardless of governments' declared objectives of introducing public mass modern education, its factual impact on both human capital accumulation and inequality is controversial. First, on the human capital accumulation front, Fritz Ringer (1979) and Claudia Goldin and Lawrence Katz (2003 and 2009) documented historically different roles of the central government in the provision of mass education in Western Europe versus North America, hence suggesting that there is no unique optimal path to generate a rapid accumulation of human capital. The evidence from developing countries is also mixed. While Esther Duflo (2001) showed that state's expansion of the quantity of schools has a positive impact on economic outcomes, other scholars such as Lant Pritchett (2001), Paul Glewwe (2002), and Eric Hanushek and Ludger Woessmann (2007) suggested that public mass education programs are often characterized by a deterioration in the quality of schools and a surge in the employment share of the public sector. In a similar vein, Donald Cox and Emmanuel Jimenez (1991) and Geeta Kingdon (1996) estimated the quality differences between public and private schools finding that they are in favor of the latter. Second, on the inequality front, the impact of public mass education on inequality, both overall and across groups, remains to be, to the best of my knowledge, an unresolved question. On the one hand, scholars of nationalism in political science such as Eugène Weber (1976), Ernest Gellner (1983), and Anthony Smith (2003) emphasized public mass education as a fundamental channel of state formation and nation-building. Apart from its impact on creating a common identity across heterogeneous ethno-religious groups, public mass education may mitigate intergroup human capital inequality which could potentially lead to inter-group conflicts. On the other hand, 
however, there is little empirical evidence on whether public mass education indeed mitigates human capital differences between groups.

This article provides novel empirical evidence on the impact of introducing public mass education on inter-group human capital inequality from an understudied region, the Middle East, and from one of its largest countries, Egypt. Following a long medieval tradition, Christians in Egypt (6 percent of the population) had, on average, better educational and occupational attainment than Muslims. In 1996 Egypt, 30 percent of adult active Muslim males who aged 35 to 65 worked in white-collar jobs, compared to 43 percent among Christians. ${ }^{1}$ After a military coup that overthrew the monarchy in 1952 and ended the de facto British Colonization in 1956, Egypt embarked on a pioneering state-led development program in the region. In the educational arena, the post-1952 regime expanded on the public mass education policies that were first introduced by Taha Hussein, a prominent liberal intellectual and Egypt's minister of Education from 1950 to 1952. In 1951-1953, as the final stroke in a century-long process of unifying the dichotomous traditional and modern educational systems, the government transformed traditional "elementary" (awwaliya) schools (kuttabs), which enrolled 70 percent of students in 1948/49, into public modern "primary" (ibtida'iya) schools (Amir Boktor 1963, pp. 27-28). ${ }^{2}$ Prior to the reform modern primary schools were de facto the sole route to secondary schools, university education, and white-collar jobs, whereas kuttabs qualified their graduates to only religious (Muslim or Christian) higher education institutes (Boktor 1936, p. 123; Mohammed Harby and El-Sayyed El-Azzawi 1960).

Although the reform entailed partial improvement of equipment and facilities in kuttabs to match those in primary schools and the construction of new primary, preparatory, and secondary schools, these measures were limited in scope. Similarly, the reform barely altered the curriculum in kuttabs, which almost converged to that of primary schools by 1949. Instead, the reform essentially meant the "re-labeling" of

\footnotetext{
${ }^{1}$ Author's calculations based on the individual-level 10 percent sample from the 1996 population census. The sample is restricted to Egyptian active Muslim and Christian males who aged 35 to 65 and are born in Egypt with non-missing values on age, province of birth, literacy, and occupation.

${ }^{2}$ Author's calculations based on the 1948/49 school census.
} 
kuttabs as public modern primary schools, loosening the entry requirements to post-primary education, and increasing class size in primary, preparatory, and secondary schools in order to absorb the surge in student enrollment. In addition to these policies, as documented by Ragui Assaad (1997), the government abolished tuition fees in public universities in 1961 and introduced in 1961-1964 an employment guarantee in the government and public sectors for graduates of secondary schools and universities, a policy that lasted until the 1983 graduates. As a result of these policies, the supply of modern schools (per 1,000 population of age 5 to 19) more than doubled from 0.44 in $1951 / 52$ to 0.96 in $1959 / 60,{ }^{3}$ and according to Alan Richards (1992) and Assaad (1997), primary enrollment rose from 1 million students in 1952 to nearly 3.5 million in 1965/66, and preparatory and secondary enrollment expanded even faster, multiplying six fold and threefold respectively, from 1956 to 1961.

Conceptually, the 1951-1953 reform increased the supply of primary schools and thus reduced the cost of access to higher stages of education and white-collar jobs. This may have improved children's educational and occupational attainment among those who had pent-up demand for modern schooling; those who would have otherwise chosen modern primary schools but were constrained by their limited supply, relative to kuttabs, in their districts of birth. The effects may vary by religious group, however, if there were inter-group differentials in enrollment in modern primary schools prior to 1951. Indeed, in 1948/49, Christian children who aged 5 to 19 years had higher student enrollment rates (49 percent) than Muslims (36 percent), with 71 percent of Christian students enrolled in modern, mostly private, schools, compared to only 25 percent among Muslim students most of whom were enrolled in public schools.

I examine the impact of the 1951-1953 reform on the educational and occupational attainment among each of Muslims and Christians, by matching two novel data sources: (a) the individual-level 10percent 1986 population census sample that has information on religion, education, occupation, and year and district of birth (but has no information on income), and (b) the district-level 1951/52 school census. I restrict the analysis to Egyptian Muslim and Christian males who were born in Egypt and aged 0-19 years in

\footnotetext{
${ }^{3}$ Author's calculations based on the school censuses of 1951/52 and 1959/60 and the population censuses of 1947 and 1960. Modern schools include primary, preparatory, and secondary schools and universities.
} 
1953 with non-missing values on age, education, occupation, and district of birth. Following Duflo (2001), two factors determine the exposure of an adult male in 1986 to the 1951-1953 reform: year of birth and the intensity of the reform in his district of birth, where I allow the effect of the reform to vary by religious group. I measure the reform intensity by the share of kuttabs out of the total number of kuttabs and modern schools, or alternatively, out of total male student enrollment, in an individual's district of birth in 1951/52, under the presumption that the higher the relative share of kuttabs in a district the more "intense" the 19511953 reform was. I focus on two outcomes: years of schooling and an indicator variable that takes the value of one if an individual works in a white-collar job, where the experiment of interest compares (within each religious group) males who aged 0 to 5 years in 1953, and were thus poised to benefit from the reform, to those who were 11 to 15 years of age in 1953, and were thus beyond elementary schooling age by 1953 .

Using the 1986, 1996, and 2006 pooled individual-level population census samples and the decennial village/quarter-level 1897-1986 population censuses, I first document that the Christian-Muslim differences in educational and occupational attainment fell during the second half of the twentieth century. Exploiting the variation across cohorts and districts of birth in the intensity of the reform, I find that the 1951-1953 reform had a positive impact on Muslims' educational and occupational attainment, but had no statistically significant impact on Christians. However, the estimated impacts of the reform on the Christian-Muslim differences with respect to these outcomes are imprecisely estimated and statistically insignificant. I conduct a number of robustness checks in order to show that the observed improvement in Muslims' educational and occupational attainment is likely attributable to the 1951-1953 reform although I cannot completely rule out the confounding effects of other public policies that were undertaken during the same period.

The article links two lines of literature: (a) the recent economics literature on the relationship between religion and economic outcomes, starting from Rafael La Porta et al. (1997), Robert Barro and Rachel McCleary (2003), Luigi Guiso et al. (2003), and Vani Borooah and Sriya Iyer (2005), and recently, Timo Boppart et al. (2008), Sascha Becker and Woessmann (2009), and Latika Chaudhary and Jared Rubin (2011), and (b) the literature on the impact of the construction of new schools (Duflo 2001) and the shift from traditional to modern schooling on economic outcomes as in Noam Yuchtman's (2010) study on late 
Imperial China. The article is, to the best of my knowledge, the first to link the two literatures by examining the impact of public mass modern education on inter-religious educational and occupational differentials. In this respect, the article adds a policy perspective to the economics of religion literature by examining the role that public policies may play in mitigating inter-religious human capital inequality. The novelty of the research question stems from the relevance of the 1951-1953 reform to the experiences of many developing countries in the post-Colonial Era in their attempts to unify the traditional and modern educational systems. Interestingly, the reform involved little improvement in the quality of kuttabs (it may have even dropped) and limited construction of new schools.

The article also contributes to Middle Eastern and Egyptian history. Scholars of education in the region such as James Heyworth-Dunne (1938), and recently Selçuk Somel (2001), emphasized that transforming the traditional educational system was arguably at the core of Egypt's and the Ottoman Empire's quest for modernization since at least the nineteenth-century. Roderic Matthews and Matta Akrawi (1949) and Joseph Szyliowicz (1973) suggested that Egypt's century-long, and mostly top-down, experience in introducing a unified primary education system was in many ways similar to that of other countries in the region. The process was slow and non-linear though as it was faced by various obstacles including the resistance of the Muslim religious elites, the lack of well-trained teachers, and, equally important, the challenge of introducing a unified curriculum that embraces the native non-Muslim minorities. The article contributes to this debate via providing the first empirical analysis of Egypt's public mass education reform in 1951-1953 (Harby and El-Azzawi 1960; Boktor 1963; Cochran 1986). The article also presents the first quantitative evidence on the evolution of the Christian-Muslim socioeconomic differences in one of the region's largest countries as opposed to the previous, mostly qualitative, literature including Jacques Tagher 1998 [1951], Charles Issawi (1981), and Youssef Courbage and Philippe Fargues (1997).

\section{Egypt's Educational System and the 1951-1953 Reform}

Up to 1800, Egypt's educational system was composed of religious schools at both the elementary (kuttabs) and higher education levels. Kuttabs were segregated by religion and were funded privately by each 
religious group's private pious endowments (waqf). ${ }^{4}$ Modern schools were introduced to Egypt in the late eighteenth century, and existed parallel to religious schools until 1951, where they continued to serve a relatively small share of the population (enrolled 30 percent of students in 1948/49). The modern educational system started with "primary" (ibtida'iya) schools that led to secondary schools and universities, the gateway to white-collar occupations. These schools taught secular subjects (arithmetic, geometry, and science), and had qualified teachers and good equipment and facilities (Boktor 1936, p. 123-4). ${ }^{5}$ There were three types of modern schools. First, there were public schools, which enrolled 59 percent of modern schools' students in 1948/49. Public modern schools were introduced to Egypt in 1816 under Muhammad Ali Pasha the autonomous Ottoman viceroy (1805-1848). Tuition fees were imposed on these schools in 1907 under the British Occupation (1882-1922) and remained in effect until 1944, where they were abolished at the primary level (Harby and El-Azzawi 1960, p. 33). Second, there were Egyptian private schools, which enrolled 32 percent of modern schools' students in 1948/49, and belonged to Egyptian Muslim, Coptic, Jewish, and other non-Muslim communities. Finally, there were foreign private schools, which enrolled 9 percent of modern schools' students in 1948/49, and according to Girgis Salama (1963, pp. 31-35), belonged to either foreign Christian missionaries or foreign secular entities. ${ }^{6}$

\footnotetext{
4 There were important quality differences between Muslim and Christian kuttabs. Whereas Muslim kuttabs taught only Arabic orthography and Quran, Christian kuttabs taught arithmetic and geometry in addition to orthography and religion (Heyworth-Dunne 1938, pp. 2-7, 85).

${ }^{5}$ Religion constituted 6 percent of the weekly periods in a public modern primary school in 1929. Subjects taught included: Religion, Arabic, English, Arithmetic and Geometry, Science and Hygiene, Geography and History, Drawing, and Physical Training (Boktor 1936, p. 124).

${ }^{6}$ Author's calculations based on the 1948/49 school census. Public modern schools included schools under the Ministry of Education, Cairo University, Administration of Religious Institutes, Waqf Administration, and other governmental entities. Egyptian private modern schools included (1) Muslim schools under private Muslim waqfs, charity Muslim organizations, and other private Muslim entities, (2) Coptic schools under the Coptic Orthodox Church, charity Coptic organizations, and other private Coptic entities, (3) Jewish schools, (4) Armenian and other Egyptian non-Muslim schools. Foreign private modern schools were mainly American, British, German, Italian, French, and Greek.
} 
The parallel religious educational system started with kuttabs, which enrolled 70 percent of students in 1948/49. Traditionally, Kuttabs qualified their graduates to higher religious (Muslim or Christian) institutions, but not to secondary schools or universities. For over a century, the government attempted to unify the two systems by merging kuttabs and public modern primary schools. In 1916, kuttabs were transformed into tuition-free four-grade "elementary" (awwaliya) schools offering a modernized and standardized curriculum with presumably no segregation between Muslim and Christian students. Since then, kuttabs (now, elementary or awwaliya schools) became increasingly administered, or at least subsidized, by the state. In 1945, graduates of elementary schools were allowed to sit for the end-of-primary-school examination that served as the entry examination to secondary schools, hence granting those students de jure access to post-primary schooling. By 1949, the curricula of public kuttabs and public modern primary schools were unified except for the foreign language requirement that started from the third grade in the latter. However, despite these measures, the $d e$ facto separation of the two systems persisted, and kuttabs' graduates were in practice not admitted to secondary schools unless they transferred first to a modern primary school.

It was under Law 143 of 1951, issued a few months before the 1952 coup and implemented in 1952/53, that the government unified public kuttabs and public modern primary schools. This was achieved via placing all kuttabs in Egypt under the supervision of the Ministry of Education, and renaming them as primary schools that allow students to advance to post-primary education. Following the coup, the post-1952 regime issued in May 1953, apparently as one of its top priorities, Law 210 of 1953 (implemented in 1953/54), which replaced the 1951 law and completed the unification process via omitting the foreign language requirement from primary schools and allowing students in the now-unified primary schools to advance throughout their first four primary school years if only they attended 160 school days in a given school year. The two laws increased compulsory years of schooling in the unified primary schools from four to six years where children were allocated to the closest primary school to their residence. ${ }^{7}$

\footnotetext{
7 The 1951 and 1953 laws both fixed the starting age of schooling at six and increased the years of compulsory schooling from four to six by including the two kindergarten years. The compulsion itself was not a new policy though since it was first dictated by the 1923 constitution and was never implemented because of the limited supply of elementary and
} 
The reform was accompanied by partial improvement of equipment and facilities in the transformed public kuttabs and the construction of new primary, preparatory, and secondary schools in order to absorb the increase in student enrollment. However, comparing the total number of kuttabs and modern schools in $1951 / 52$ to that of modern schools in 1959/60 shows a very modest increase of 2.5 percent. This suggests that the increased enrollment in primary, preparatory, and secondary schools, was mostly absorbed via increasing class size. In addition, the government made education in public universities free of charge in 1961 (public primary and secondary schools were already made free of charge in 1944 and 1950 respectively), and initiated, starting from 1961, an employment guarantee scheme in the government and public sectors to university graduates, which was then extended to graduates of secondary schools and formalized in Law 14 of 1964. This guarantee lasted until the 1983 graduates (Assaad 1997).

Figure I depicts Egypt's supplies of kuttabs and modern schools (the latter include primary, secondary, and higher-education schools) per 1,000 school-age population between 1906/07 and 1969/70, based on the triennial school censuses. Between 1906/07 and 1951/52, the population-adjusted supply of kuttabs was about five times that of modern schools. While modern schools remained stable throughout the period, kuttabs witnessed a few fluctuations, especially in the 1920s, where they increased presumably as a result of an expansion program after Egypt's (nominal) independence from Britain in 1922. ${ }^{8}$ Nevertheless, the major structural break in Egypt's educational history came after 1951/52, as kuttabs were transformed into public modern primary schools causing a sharp increase in modern schools supply.

Figure II shows the sectoral composition of kuttabs and modern schools between 1906/07 and 1969/70. Public kuttabs that were administered by the Ministry of Education or local provincial councils, whose share was negligible in 1906/07, increasingly substituted private kuttabs to reach 67 percent of all kuttabs in 1948/49 and then 100 percent in 1951/52. The latter development was part of the 1951-1953

primary schools. The 1953 law made primary enrollment compulsory for children only if there were a sufficient number of primary public schools within two kilometers from their place of residence.

8 This was an implementation of the 1923 constitution that provided free and compulsory education for every child between 6 and 12 years. 
reform. Similarly, within modern schools, the share of public schools increased between 1906/07 and 1951/52. Together, these trends indicate that the first half of the twentieth century witnessed increased state intervention in education via administering the traditionally private kuttabs and increasing public provision of modern schools.

\section{The Evolution of the Christian-Muslim Educational and Occupational Differentials in the Twentieth Century}

Although the existence of educational and occupational differentials between Christians and Muslims

in Egypt, or, more generally, between native non-Muslim minorities and the Muslim majority in the Middle East at large, has been long noted qualitatively in the literature (Tagher 1998 [1951]; Issawi 1981), the quantitative evidence on the phenomenon and its evolution over time remains rather scanty. To the best of my knowledge, only Courbage and Fargues (1997) provided quantitative evidence on the magnitude of the inter-religious differentials in birth, death, and literacy rates in a number of countries in the region. In this section, I employ two data sources to document the evolution of the inter-religious educational and occupational differentials in Egypt throughout the twentieth century. First, I use the pooled 1986, 1996, and 2006 individual-level 10-percent population census samples in order to document the average educational and occupational attainment by cohort of birth among Christian and Muslim males who aged 30-60 years in each census. Second, I use the decennial village/quarter-level population censuses in 1897-1986, where I regress the average educational and occupational attainment at the village/quarter-level on the percentage of nonMuslims in the village/quarter allowing the coefficient of non-Muslims to vary across census years. This documentation allows me to identify the structural breaks in the long-term trends of the Christian-Muslim human capital differentials.

\section{A. Evidence from the Pooled 1986, 1996, and 2006 Individual-Level Population Census Samples}

The six panels of Figure III depict the average educational and occupational attainment by religion and cohort of birth and the corresponding Christian-Muslim differences. The graphs are based on the pooled 1986, 1996, and 2006 individual-level 10-percent population census samples, where the sample is restricted to Egyptian Christian and Muslim males who were born in Egypt and aged between 30 and 60 years in 1986, 
1996, or 2006, with non-missing values on age, religion, province of birth, and education. I measure educational attainment by: (a) years of schooling which I assign according to the highest educational degree achieved (available in 1986 and 2006 only), and (b) literacy, which is a dummy variable that takes the value of one if the individual knows how to read and write. I measure occupational attainment by a dummy variable that takes the value of one if the occupation is white-collar (defined for the working population only), which includes the top four major occupational groups according to the International Standard Classification of Occupations (ISCO): (1) legislators, senior officials, and managers, (2) professionals, (3) technicians and associate professionals, and (4) clerks. ${ }^{9}$ Because people do not remember their age, the age distribution in the pooled 1986, 1996, and 2006 census sample exhibits heaps around multiples of five, a common problem in censuses from developing countries. To mitigate this problem, I constructed 5-year-window cohorts of birth centered on heap years: 1926, 1931, and so on.

The left-hand-side panels of Figure III show that Christians in all cohorts have, on average, more years of schooling, a higher literacy rate, and a greater share of white-collar workers, than Muslims.

Interestingly, although there was secular improvement across cohorts of birth in educational attainment (both years of schooling and literacy), occupational attainment, measured by the share of white-collar workers, deteriorated among both Christians and Muslims starting from the cohort born in 1964-1968. In order to explore this anomalous finding in more depth, I depicted the trends of the occupational subcategories that

\footnotetext{
9 This is the 1-digit 1988 ISCO classification which is available in both the 1996 and 2006 samples. Whereas the 1996 sample reports this aggregated classification only, the 2006 sample provides a more detailed (3-digit) classification. Although the 1986 sample reports the most detailed (5-digit) classification, it employs a different occupational scheme, the 1985 Egyptian classification of occupations, itself a modification of the older 1968 ISCO classification. The "whitecollar" indicator includes in the 1986 sample classification the following occupational groups: (a) personnel in technical, scientific, and professional occupations, (b) officials, managers, business managers, and business owners who work in their own businesses but are not classified elsewhere (except those working in trade, services, and agriculture), (c) clerks and personnel in administrative occupations, (d) managers of wholesale and retail trade businesses, (e) managers of hotels and restaurants, (f) managers of entertainment and personal services, and (g) managers of agricultural farms.
} 
fall under the "white-collar" definition. The findings of this exercise are in section (A) of the online appendix but I summarize them here. Basically, it appears that the upward-then-downward trend of the share of whitecollar workers is primarily driven by the movements in the population share of professionals (mostly, teachers and accountants) followed by clerks. Although the downward trend seems surprising at first sight, it is actually consistent with Assaad's (2014) findings from the 2006 Egyptian Labor Market Survey. One possible explanation is the suspension, starting from the cohort that graduated in 1983, of the employment guarantee in the government and public sector, which was presumably behind the improvement in occupational attainment up to the cohort born in 1959-1963 since most government and public sector employees were white-collar workers. ${ }^{10}$

The right-hand-side panels of Figure III show the Christian-Muslim differences in the three outcomes along with the 95-percent confidence intervals. The differences in educational and occupational attainment declined beginning from the cohort born in 1949-1953 that presumably benefited from the 19511953 reform, although there is an earlier convergence in literacy among the cohorts born in 1929-1943.

\section{B. Evidence from the Village/Quarter-Level Population Censuses in 1897-1986}

Since the 1986, 1996, and 2006 individual-level census samples include only the survivors in these years, I also document the inter-religious educational and occupational differentials using the decennial village/quarter-level population censuses in 1897-1986 that enumerated the entire population at the time of

\footnotetext{
10 The occupation reported in the population censuses is the "primary" occupation and so one may be concerned that it does not capture an individual's real occupational status if she has multiple jobs. This, the argument goes, may somehow account for the observed deterioration in occupational status if the younger cohorts were more likely to hold multiple jobs. Indeed, the 2006 Egyptian Labor Market Panel Survey (ELMPS) indicates that two thirds of active males who aged 30 to 60 years held a second job. However, as people who hold multiple jobs tend to report the higher status job as their primary occupation, this likely overstates their occupational status. For example, among males in the ELMPS who hold two jobs and report a "non-white-collar" primary job, only 5 percent report a "white-collar" second job. Therefore, even if younger cohorts were more likely to hold multiple jobs, their higher overstatement of occupational status (on average) implies that the real deterioration is actually greater than what is observed.
} 
each census. These published census reports were digitized by the Centre d'Etudes et de Documentation Economiques, Juridiques, et Sociales (CEDEJ 2003). I matched villages/quarters across the censuses using the 1996 census mapping provided by CEDEJ, but I supplemented this mapping by matching names of villages/quarters that do not have a mapping in the 1996 census. This resulted in an unbalanced panel dataset at the village/quarter-level. There are a number of caveats in these censuses, however, and hence the results must be interpreted with caution. First, the data are aggregated at the village/quarter-level, the lowest administrative level in Egypt, but are not available at the individual-level. Second, the variables vary from one census to another on an arbitrary basis, thus limiting the control variables that could be included in the regression analysis. Third, and most importantly, the educational and occupational outcomes are not broken down by religion.

I pooled the decennial village/quarter-level censuses from all years and estimated the following OLS regression: ${ }^{11}$

$$
\text { (1) } y_{i t}=\alpha_{i}+\beta_{t}+\text { nonmuslimshare }_{i t} \boldsymbol{\gamma}_{\boldsymbol{t}}+\boldsymbol{X}_{\boldsymbol{i t}} \boldsymbol{\delta}_{\boldsymbol{t}}+\varepsilon_{i t}
$$

Where $y_{i t}$ is the outcome of interest in village/quarter $i$ in census year $t$. There are two outcomes: the percentage of males who are able to read and write and the percentage of males who work in the nonagricultural sector. In order to ensure comparability across census years, I calculated both percentages out of the total male population including children. $\alpha_{i}$ are village/quarter fixed effects, which capture the village/quarter-level time-invariant characteristics, $\beta_{t}$ are census year fixed effects, which capture aggregate shocks that may have affected all villages/quarters in a given census year, nonmuslimshare $e_{i t}$ is the percentage of non-Muslims in the village/quarter, $X_{i t}$ is a vector of village/quarter-level time-variant control variables, and $\varepsilon_{i t}$ is an error term. Control variables include $(\log )$ population, the percentage of females, the percentage of the population under 10 years, the percentage of the population who are at least 60 years, and the percentage of foreigners. In this specification, I allow the marginal effects of the percentage of nonMuslims (and of the control variables) to vary by census year. $\gamma_{t}$ could be interpreted as an estimate of the

\footnotetext{
${ }^{11}$ I also estimated the regression without village/quarter fixed effects and I obtained similar results.
} 
difference between non-Muslims and Muslims in census year $t$ with respect to the outcome of interest. Since I include village/quarter fixed effects, I exploit here the within-village/quarter variation in non-Muslims' population share in 1897-1986. However, because I do not observe the outcomes broken down by religion, $\gamma_{t}$ should be interpreted with caution since there might be other omitted village/quarter-level time-varying characteristics that are correlated with both non-Muslims' population share and the educational and occupational outcomes.

The decennial estimates of $\gamma_{t}$ for the two outcomes are shown in the two panels of Figure IV. Panel (A) suggests that the literacy gap between non-Muslims and Muslims, which was initially in favor of nonMuslims, dropped between 1937 and 1947, remained stable between 1947 and 1960, declined further between 1960 and 1976, and then remained stable between 1976 and 1986. A one-percentage point increase in nonMuslims' population share is correlated, on average, with an increase in the percentage of males who are able to read and write by 28 percentage points in 1897 but by only 12 percentage points in 1986 . The trend of the inter-religious literacy gap is qualitatively robust to the inclusion of the control variables.

Panel (B) shows that the occupational gap that was in favor of non-Muslims started to decline between 1960 and 1976. A one-percentage point increase in non-Muslims' population share is correlated, on average, with an increase in the percentage of males working in the non-agricultural sector by 26 percentage points in 1927 but by only 3 percentage points in 1986 .

Overall, the estimated trends from the village/quarter-level censuses in 1897 to 1986 suggest that the inter-religious educational and occupational gaps declined between 1960 and 1976. This seems to be consistent with the trends across cohorts of birth of the inter-religious differences in the average years of schooling, the literacy rate, and the percentage of white-collar workers, which were documented in Figure III, thus suggesting that the convergence in Christians' and Muslims' educational and occupational attainment started from the cohort born in 1949-53. Basically, the observed village/quarter-level decline in the interreligious educational and occupational gaps between 1960 and 1976 could be attributed to the fact that most of the cohort born in 1949-53 had completed schooling and entered the labor market by 1976 (this cohort aged 23 to 28 years in 1976). 
Finally, it should be noted that both the 1986-2006 individual-level census data and the 1897-1986 village/quarter-level census data demonstrate an earlier decline in the inter-religious literacy gap among the cohorts born between 1929 and 1943 or between the census years 1937 and 1947. One may speculate that the earlier decline was caused by the state's policies since Egypt's nominal independence in 1922 to expand on, improve the quality of, or increasingly provide, public schooling (Figures I and II). ${ }^{12}$

\section{Hypothesis}

The transformation of kuttabs into public modern primary schools under the 1951-1953 reform increased the supply of primary schools, and reduced the cost of access to higher stages of education and white-collar jobs. Hence, it should have increased the optimal parental investment in human capital (child's years of schooling), leading to better occupational attainment, among the supply-constrained parents. These are parents who had unsatisfied demand for schooling; they would have otherwise chosen modern primary schools for their children, because they provided access to higher stages of education and/or white-collar jobs, but could not do so because of the limited supply of these schools relative to kuttabs in their districts of residence (equivalently, their children's districts of birth). Three notes are in order. First, the 1951-1953 reform did not reduce the tuition cost of enrollment in public modern primary schools, which were in fact made free of charge, just like public kuttabs, since 1944. Second, the reform did not change the curriculum of kuttabs, which almost converged to that of primary schools by 1949. Third, the expected improvement in child's occupational attainment may be explained by two mechanisms, (a) a market mechanism, where the increase in human capital that results from the increase in years of schooling is translated into a better occupational attainment or a higher probability of working in a white-collar job, and (b) a non-market mechanism, where the 1964 employment guarantee in the government and public sectors for secondary schools and university graduates may have improved occupational attainment regardless of the actual human capital accumulation. Both mechanisms do not differ, at least in principle, across Christians and Muslims.

${ }^{12}$ It is not possible to examine the impact of the expansion of kuttabs between 1921/22 and 1927/28 that is shown in Figure I using the 1986, 1996, and 2006 census samples because the birth cohorts that were poised to benefit from the expansion (presumably born in 1917-1923) are too old to be observed in 1986, 1996, or 2006. 
The effect of the reform may differ across Christians and Muslims if there were differences in enrollment in modern schools prior to 1951. First, Figure V shows that Christians had higher student enrollment rates than Muslims in 1907/08-1948/49, with a persistent gap throughout the period, albeit with a few fluctuations. Second, Figure VI shows the educational choices across kuttabs and modern schools (including, public, Egyptian private, and foreign private schools) among Christian and Muslim students. 96 percent of Christian students in 1907/08 were enrolled in modern schools (66 percent in foreign private schools, 25 percent in Egyptian private schools, and 5 percent in public schools), as opposed to only 24 percent among Muslim students (16 percent in Egyptian private schools, 5 percent in public schools, and 3 percent in foreign private schools). Although the share of students enrolled in kuttabs increased steadily among Christian students in 1907/08-1948/49, perhaps because of the increased enrollment of poorer Christian children, the majority of Christian students (71 percent) in 1948/49 resorted to modern schools. By contrast, the share of students enrolled in kuttabs among Muslim students remained stable at 75 percent in 1948/49 with only 25 percent enrolled in modern schools.

These equilibrium choices reflect both the supply and demand for education. But why were Christian students more likely to enroll in modern schools to begin with? First, they were more likely to afford tuition fees in non-free modern schools. Second, non-Muslim communities were over-represented in the ownership of Egyptian private modern schools, which enrolled 27 percent and 7 percent of Christian and Muslim students respectively in 1948/49. According to Figure VII, the Coptic Christian community (7 percent of the population in 1947) owned 37 percent of Egyptian private modern schools, compared to 46 percent owned by the Muslim community, which suggests that Christians were relatively more active than Muslims in providing private modern education to their children and hence relied relatively less on public schools.

\section{Data}

I examine the impact of the expansion of mass education in 1951-1953 on the educational and occupational differences between Christians and Muslims using the 1986 individual-level 10-percent census 
sample, which, unlike the more recent 1996 and 2006 census samples, reports the district of birth. ${ }^{13}$ I restrict the sample to Egyptian Christian and Muslim males who were born in Egypt between 1934 and 1953, and thus aged 0 to 19 years in 1953, with non-missing values on age, religion, district of birth, and education. The census sample is then matched, on individual's district of birth, to the 1951/52 district-level school census, which I digitized from the Annuaire Statistique 1949-1950 et 1950-1951 (1953, pp. 260-71). ${ }^{14}$ There are two outcomes of interest in the 1986 census sample: (a) educational attainment, which I measure by years of schooling, and (b) occupational attainment, which I measure by the white-collar occupation dummy variable.

In order to mitigate the concern of mean reversion in human capital across districts, I include controls for district-level health characteristics in 1951/52, which I measure by (i) the number of deaths and maladies due to infectious diseases per 1,000 population and (ii) the number of hospital beds per 1,000 population; I digitized both variables from the Annuaire Statistique 1949-1950 et 1950-1951 (1953, pp. 144-77).

Table I shows the individual-level descriptive statistics for Christians and Muslims along with the district-level statistics for the district-level variables. Christians have, on average, more years of schooling and a greater percentage of white-collar workers than Muslims. The average shares of kuttabs in an individual's district of birth in 1951/52, out of the total number of kuttabs and modern schools and of total male student enrollment, are lower among Christians than Muslims, indicating that modern schools were relatively more widespread in Christians' districts of birth. It seems, however, that there are no differences in health outcomes in the district of birth in 1951/52 between Christians and Muslims.

\section{Empirical Strategy}

Does the expansion of mass modern education in 1951-1953 explain part of the observed convergence in educational and occupational attainment between Christians and Muslims in Egypt in the

\footnotetext{
13 The 1996 and 2006 individual-level census samples report the province of birth and not the district of birth. The small number of provinces $(\sim 20)$ is not sufficient for the regression analysis.

14 There are 451,314 Egyptian Christian and Muslim males born in Egypt between 1934 and 1953 in the sample. Dropping those with missing age, religion, district of birth, or education resulted in a sample size of 440,569 observations. Merging the sample with the 1951/52 district-level school census resulted in a final sample size of 426,801 .
} 
mid-twentieth century? In order to identify the impact of the reform on each religious group, and following Duflo (2001), I exploit the variation across cohorts and districts of birth in their exposure to the reform. Two variables determine an individual's exposure to the 1951-1953 reform: year of birth and intensity of the 19511953 reform in an individual's district of birth measured by the relative share of kuttabs in the provision of schooling on the onset of the reform. Specifically, I estimate the following OLS regression:

(2) $y_{\text {irjt }}$

$=\left(P_{j} T_{i}\right) \delta_{1}+\left(C_{i} P_{j} T_{i}\right) \delta_{2}+\left(\boldsymbol{X}_{\boldsymbol{j}} T_{i}\right) \boldsymbol{\delta}_{\mathbf{3}}+\left(\boldsymbol{X}_{\boldsymbol{j}} C_{i} T_{i}\right) \boldsymbol{\delta}_{\mathbf{4}}+\boldsymbol{\alpha}_{\boldsymbol{r}}+\boldsymbol{\beta}_{\boldsymbol{j}}+\boldsymbol{\gamma}_{\boldsymbol{t}}+\boldsymbol{\alpha}_{\boldsymbol{r}} * \boldsymbol{\beta}_{\boldsymbol{j}}+\boldsymbol{\alpha}_{\boldsymbol{r}} * \boldsymbol{\gamma}_{\boldsymbol{t}}+\varepsilon_{i r j t}$

Where $y_{\text {irjt }}$ is the educational or occupational attainment of an individual $i$ from religious group $r$ (= Christian or Muslim) born in district $j$ in year $t . T_{i}$ is an indicator variable for being in the "young" or the "treated" cohort that was poised to benefit from the reform. $P_{j}$ is the intensity of the reform in an individual's district of birth, which I measure by two alternative variables both of them observed in 1951/52: (i) the relative share of kuttabs out of the total number of schools (both kuttabs and modern schools) and (ii) the relative share of kuttabs out of total male student enrollment (because the first measure does not take into account differences in size between kuttabs and modern schools). $C_{i}$ is an indicator variable for being

Christian. $\boldsymbol{X}_{\boldsymbol{j}}$ is a vector of control variables that measure the baseline health characteristics in each district of birth in 1951/52 that I described in the previous section.

$\alpha_{r}, \beta_{j}$, and $\gamma_{t}$ are vectors of fixed effects indicating an individual's religious group, district of birth, and year of birth respectively, which control for differences in educational or occupational attainment across religious groups, districts of birth, and years of birth. The interaction terms $\alpha_{r} * \beta_{j}$ and $\alpha_{r} * \gamma_{t}$ are introduced in order to control for the possibility that cross-district or cross-cohort differences in educational or occupational attainment may vary by religious group. Standard errors are clustered the district of birth level. $\varepsilon_{\text {irjt }}$ is an error term.

Equation (2) is a straightforward extension of the difference-in-differences strategy in Duflo (2001). In this specification, the effect of the 1951-1953 reform on Muslims is given by $\delta_{1}$, which captures the differential growth in educational or occupational attainment between Muslims from high-reform districts and 
their coreligionists from low-reform districts. Similarly, the effect of the reform on Christians is captured by $\delta_{1}+\delta_{2}$, whereas $\delta_{2}$ measures the effect of the reform on the Christian-Muslim difference in educational or occupational attainment.

The identifying assumption of the effect of the 1951-1953 reform on each religious group is that there are no time-varying district-specific omitted variables $\left(\boldsymbol{Z}_{\boldsymbol{j} \boldsymbol{t}}\right)$ that are correlated with both the intensity of the 1951-1953 reform and the observed growth in educational or occupational attainment. The assumption is violated, for example, if there were mean reversion in educational and occupational attainment across districts even in the absence of the reform. It is also violated if there were other public programs that were carried out during the same period and that might have driven (within each religious group) the differential growth in educational or occupational attainment across districts. I address both threats in the robustness checks.

Two notes are in order: First, religion in the 1986 census is self-reported in four categories: Muslim, Christian, Jew, and other. Given the inheritability of religion and the (near) impossibility of conversion, I treat religion as an inherited demographic trait that is similar to race. In other words, the objective of my analysis is not to estimate the causal impact of religion on economic outcomes, but rather the effect of providing mass education on the accumulation of human capital among each religious group and if the effect varied across Christians and Muslims. Second, occupational attainment is defined for the working population only, but since I am interested in the impact of the 1951-1953 reform on the Christian-Muslim difference in occupational attainment, the concern about self-selection of workers is mitigated so long as there are no differences in labor force participation between the two groups, a claim that is supported by the data. ${ }^{15}$

I estimate three sets of regressions. I first estimate equation (2) on the "experiment of interest," in which I compare the treated cohort, those who aged 0-5 years in $1953(T=1)$ and were hence poised to benefit from the reform because they were just about to enter primary schools or kuttabs, to the control cohort, those who aged 11-15 years in $1953(T=0)$ and were just too old to benefit from the reform because they were past their kuttabs' schooling years (there were four years of elementary schooling between 6 and 10

15 The employment rate among Christians is 93 percent versus 92 percent among Muslims. 
years of age). Second, I estimate a "placebo test," in which I compare those who aged 11 to 15 years to those who aged 16 to 19 years in 1953. Since both cohorts were presumably too old to benefit from the reform, one expects to find no effect of the program there. Third, I re-estimate the regression where I include interactions of the reform intensity with a full set of cohort of birth indicators. Given the problem of age heaping in the sample, I constructed four cohorts of birth centered on heap years, 1936, 1941, 1946, and 1951:

(3) $y_{\text {irjt }}$

$=\sum_{l=2}^{4}\left(P_{j} d_{i l}\right) \delta_{1 l}+\sum_{l=2}^{4}\left(C_{i} P_{j} d_{i l}\right) \delta_{2 l}+\sum_{l=2}^{4}\left(\boldsymbol{X}_{\boldsymbol{j}} d_{i l}\right) \boldsymbol{\delta}_{\mathbf{3 l}}+\sum_{l=2}^{4}\left(\boldsymbol{X}_{\boldsymbol{j}} C_{i} d_{i l}\right) \boldsymbol{\delta}_{\mathbf{4 l}}+\boldsymbol{\alpha}_{\boldsymbol{r}}+\boldsymbol{\beta}_{\boldsymbol{j}}+\boldsymbol{\gamma}_{\boldsymbol{t}}+\boldsymbol{\alpha}_{\boldsymbol{r}} * \boldsymbol{\beta}_{\boldsymbol{j}}+\boldsymbol{\alpha}_{\boldsymbol{r}}$ $* \gamma_{t}+\varepsilon_{\text {irjt }}$

Where $d_{i l}$ is a dummy variable that indicates if an individual belongs to cohort $l$, with $l=1$ for the 1936 cohort (born in 1934-1937), which is the base cohort, $l=2$ for the 1941 cohort (born in 19381942), $l=3$ for the 1946 cohort (born in 1943-1947), and $l=4$ for the 1951 cohort (born in 1948-1953). In this specification, $\delta_{14},\left(\delta_{14}-\delta_{12}\right)$, and $\left(\delta_{14}-\delta_{13}\right)$ capture the differential effects of the 1951-1953 reform on the treated cohort of Muslims relative to its effects on each of the three older cohorts. The differential effects of the reform on the treated cohort of Christians relative to its effects on each of the three older cohorts are given by $\left(\delta_{14}+\delta_{24}\right),\left(\delta_{14}+\delta_{24}\right)-\left(\delta_{12}+\delta_{22}\right)$, and $\left(\delta_{14}+\delta_{24}\right)-\left(\delta_{13}+\delta_{23}\right)$ respectively. Finally, $\left(\delta_{24}-\delta_{22}\right),\left(\delta_{24}-\delta_{23}\right)$, and $\delta_{24}$ measure the differential effects of the reform on the ChristianMuslim educational or occupational differential among the treated cohort relative to its effects on the differentials in each of the three older cohorts.

\section{Results}

The results of the three sets of regressions using the first measure of the reform intensity, the district's relative share of kuttabs out of the total number of schools in 1951/52, are shown in Tables II, III, and IV. I relegated the results using the second measure of the reform intensity, the relative share of kuttabs out of total male student enrollment in 1951/52, to section (B) of the online appendix in order to save space. I show the results on years of schooling for both the full sample and the workers' sample for comparison. 
Table II shows the results on the experiment of interest. The 1951-1953 reform had a positive impact on Muslims' educational and occupational attainment. Muslims born in high-reform districts (high share of kuttabs) experienced, on average, differentially greater increases in years of schooling and in the probability of working in a white-collar job than their coreligionists from low-reform districts. For example, Muslims born in districts at the third quartile of kuttabs' share in $1951 / 52$ (kuttabs' share $\approx 0.92)$ increased their years of schooling and their probability of working in a white-collar job differentially more than their coreligionists who were born in districts at the first quartile (kuttabs' share $\approx 0.54)$ by 0.19 year and 4 percentage points respectively, on average. The effects on Muslims are robust to adding controls for district's baseline health characteristics in 1951/52 (columns 4, 5, and 6), suggesting that the findings are not driven by mean reversion in human capital across districts.

By contrast, the 1951-1953 reform had no statistically significant effect on Christians' years of schooling as $\delta_{1}+\delta_{2}$ is positive but not statistically different from zero (columns 1 and 4). Although the effect on Christians' probability of working in a white-collar job is positive and statistically significant in column 3, it is not robust to controlling for district's health characteristics in 1951/52 in column 6 .

As to the impact of the reform on Christian-Muslim human capital inequality, although the estimated impacts of the 1951-1953 reform on the Christian-Muslim differences in years of schooling and in the probability of working in a white-collar job are mostly negative (thus, suggesting that the reform may have caused convergence in human capital between the two groups), they are not precisely estimated and are statistically insignificant. The results in Table (B.1) in the appendix, which uses the share of kuttabs out of total male student enrollment as a measure of the reform intensity, are similar to those in Table II.

Table III shows the results of the placebo test. As expected, I find no statistically significant effects of the reform on Muslims or Christians in the cohort that aged 11-15 years in 1953 compared to the cohort that aged 16-19 years in 1953, where the only exception is that $\delta_{1}+\delta_{2}$ is positive and statistically significant at the 10-percent level in column 3. Table (B.2) in the appendix, which uses the second measure of the reform intensity, shows similar results where $\delta_{1}+\delta_{2}$ in column 3 now loses its statistical significance. Overall, the 
table suggests that the improvements in Muslims' educational and occupational attainment that are observed in Table II are indeed driven by the 1951-1953 reform since they are not found among the older cohort.

Table IV shows the results of estimating equation (3), where I include interactions of the reform intensity with a full set of cohort of birth fixed effects. Overall, the results suggest that the observed growth in educational and occupational attainment among the "treated" cohort of Muslims (those who aged 0-5 years in 1953) is attributable to the 1951-1953 reform. First, the effects of the reform on Muslims in the two older cohorts, those who aged 6-10 and 11-15 years in 1953, are not statistically different from its effect on the base cohort, those who aged 16-19 years in 1953 ( $\delta_{12}$ and $\delta_{13}$ are each insignificant). Second, the effect of the reform on Muslims who aged 0-5 years in 1953 (the treated cohort) is positive and statistically different from its effects on each of the three older cohorts since $\delta_{14},\left(\delta_{14}-\delta_{12}\right)$, and $\left(\delta_{14}-\delta_{13}\right)$ are each statistically different from zero. The previous results hold for both years of schooling and the probability of working in a white-collar job, with and without controls. They also hold using the second measure of the intensity of the reform in Table (B.3) in the online appendix. The only exception here is that $\delta_{14}$ is insignificant in a few regressions suggesting that the effect of the reform on the treated cohort is not statistically different from its effect on the oldest cohort. But this seems to be a statistical power problem.

For Christians, however, the effect of the reform on the treated cohort is in most cases not statistically different from its effects on each of the three older cohorts as $\left(\delta_{14}+\delta_{24}\right),\left(\delta_{14}+\delta_{24}\right)-$ $\left(\delta_{12}+\delta_{22}\right)$, and $\left(\delta_{14}+\delta_{24}\right)-\left(\delta_{13}+\delta_{23}\right)$ are each statistically insignificant. As expected, all estimates of the program's impact on the Christian-Muslim differences in educational and occupational attainment among the treated cohort are statistically insignificant as $\left(\delta_{24}-\delta_{22}\right),\left(\delta_{24}-\delta_{23}\right)$, and $\delta_{24}$ are each not statistically different from zero.

The central findings of the paper could hence be summarized as follows. The expansion of public mass modern education, that occurred as a result of the transformation in 1951-1953 of kuttabs, that were initially made all public in 1951/52, into public modern primary schools, improved Muslims' educational and occupational attainment in terms of years of schooling and the probability of having a white-collar job but had no statistically significant impact on Christians' outcomes. Although one would expect Muslims to have 
benefited from the 1951-1953 reform differentially more than Christians in a statistical sense, the estimated impacts of the reform on the Christian-Muslim educational and occupational differences are all imprecisely estimated and statistically insignificant. This seems to be stemming from a statistical power problem (large standard errors) presumably because Christians are more concentrated in a relatively small number of districts.

I interpret the finding of statistically significant effects on Muslims but not on Christians as a result of the pre-1951 inter-religious differences in enrollment in modern schools that were in favor of Christians. In particular, since the vast majority (75 percent) of Muslim students were enrolled in kuttabs before the reform, it is the increase in the expected returns to enrollment in the transformed kuttabs via providing their graduates access to preparatory, secondary, and university education and white-collar jobs in the 1951-1953 reform, that led to Muslims' increased demand for modern schooling and the consequent improvement in their educational and occupational attainment. For Christians, however, the effects of the reform are not statistically significant perhaps because most Christian students were already enrolled in modern schools prior to 1951-1953. It must be emphasized though that the effects of the reform on Muslims are not statistically different from those on Christians, as the marginal effects of the reform on the Christian-Muslim educational and occupational differences are not precisely estimated.

\section{Robustness Checks}

There are a number of threats that could violate the identifying assumption of the effect of the 19511953 reform on Christians and Muslims in equations (2) and (3). I address some of these threats below and I refer the reader to section $(\mathrm{C})$ of the online appendix for the results of this section.

\section{A. Measurement Error}

There is a possibility of measurement error in observing years of schooling. Basically, I measured years of schooling via assigning a number of years to an individual's highest educational degree achieved. However, I do not observe the actual years of schooling if an individual dropped out of school between any two degrees. Thus, as a robustness check, I re-estimated equation (2) using alternative educational outcomes as dependent variables. In particular, I constructed five dummy variables that take the value of one if an 
individual (1) is literate, (2) finished at least primary school, (3) finished at least preparatory school, (4) finished at least secondary school, and (5) finished at least university education. The results are shown in Table C.1 in the appendix. Overall the results are qualitatively similar to those in Table II, except that the reform seems to have had a negative effect on the probability of having at least a university degree. Although the result seems paradoxical, it may be because the 1964 employment guarantee that gave positions in the government and public sector to graduates of both universities and secondary schools may have provided incentives to finish secondary schooling but fewer incentives to complete university education.

\section{B. Mean Reversion}

There is also a concern about the possibility of mean reversion in educational and occupational attainment across districts in the absence of the reform. In order to mitigate this concern, I expanded the set of controls for the baseline characteristics of districts in the vector $\boldsymbol{X}_{\boldsymbol{j}}$ beyond the two health variables by including four additional demographic variables that I observe in the 1947 population census: (i) the logarithm of population, (ii) the population share of non-Muslims, (iii) the population share of foreigners, and (iv) the share of males in elementary/primary school age (5-14 years) out of the total male population. The results are shown in Table C.2 and are qualitatively similar to the main results.

Relatedly, one may be concerned that the two measures of the reform intensity are higher in districts that had a small total number of schools on the onset of the reform. If those districts were rural, the results could then be driven by rural-urban convergence even in the absence of the reform. To this end, I reestimated equation (3) for rural-born and urban-born individuals separately. The results in Table C.3 indicate that that the effects hold within each group, although they are greater within urban-born individuals. This indicates that the results are not only driven by rural-urban convergence but rather by convergence within each group and particularly among urban-born individuals. Furthermore, Figure C.1 indicates that districts with a small number of schools are relatively few. Excluding individuals who are born in districts where there were fewer than 20 schools in 1951/52 does not alter the findings (see Table C.4).

\section{Migration and Survivorship Biases}


The reform's positive effects on Muslims may be driven by increased internal migration from rural to urban districts among the treated cohort and could thus reflect the positive returns to migration. I address this concern by excluding internal migrants, those who resided in 1986 in a different district from their district of birth. The results are in Table C.5 and are similar to the main findings.

There is an equally valid concern about increased out-migration among the treated cohort. For example, if high-skilled Christians were more likely to leave Egypt, say because of the post-1952 regime's populist policies, this could explain why we observe no effect on Christian "stayers" in 1986. It seems unlikely though that out-migration is driving the results. Out-migration from Egypt occurred in two waves, the first followed Egypt's defeat in the 1967 war and was mostly directed to North America and Western Europe, while the second and much larger wave started after the 1974 oil boom and targeted North America, Western Europe, but, more importantly, the Arab countries of the Persian Gulf. ${ }^{16}$ The treated cohort, who was born in 1948-1953, aged 14 to 19 years in 1967 and 21 to 26 years in 1974, and so it was likely affected by the second wave but not the first. Nevertheless, the second wave comprised both Muslims and Christians, since high-skilled Muslims (teachers, accountants, engineers, and physicians) were presumably equally likely to leave Egypt although for a different destination, the Persian Gulf Arab States. Moreover, the population of Egyptian-born individuals in the U.S., the largest destination of Egyptians after the Gulf States, was modest in 1930-2010 relative to the Christian population inside Egypt. ${ }^{17}$

Survivorship bias is also a concern since individuals observed in 1986 are the survivors who are likely positively selected from the population and this bias could be driving the findings. However, the placebo test shows no effect among the older cohorts, indicating that survivorship bias is not driving the findings.

\section{Confounding Public Policies}

\footnotetext{
16 An earlier out-migration wave occurred following the Suez crisis in 1956 and mostly comprised Jews and non-Coptic Christians. Egyptian Christians (mostly, Copts) were less affected by that wave though.

${ }^{17}$ According to IPUMS U.S. census samples, the estimated numbers of Egyptian-born individuals in the U.S. were 3,242 in $1930,7,374$ in 1960, 23,500 in 1970, 44,620 in 1980, 70,658 in 1990, 118,081 in 2000, and 145,172 in 2010. Christians inside Egypt numbered 1,493,055 (8 percent of the population) in 1947 and 2,869,626 (6 percent) in 1986.
} 
Perhaps most importantly, there is a concern about potential confounding public policies that were carried out during the same period within Egypt's post-1952 model of state-led development and that may be driving the results. I examine some of these policies below but this list is no way exhaustive and so I am unable to rule out this possibility completely.

Two relevant educational policies here are the abolition of tuition fees in public universities starting from 1961 and the introduction in 1961-1964 of a guaranteed employment scheme in the government and public sector for graduates of universities and secondary schools. To examine these policies more closely, I note that several cohorts were poised to benefit from them, (1) those who were about to enter primary schools in 1961 (aged 0-5 in 1961, born in 1956-1961), (2) those who were in primary-school age in 1961 conditional on having enrolled in a primary school (aged 6-12 in 1961, born in 1949-1955), (3) those who were in preparatory-school age in 1961 conditional on having enrolled in a preparatory school (aged 13-15 in 1961 or born in 1946-1948), (4) those who were in secondary-school age in 1961 conditional on having enrolled in a secondary school (aged 16-18 in 1961 or born in 1943-1945), and (5) those who were in university age conditional on having enrolled in a university (aged 19-22 in 1961 or born in 1939-1942). The cohort that was too old to benefit from the two reforms is the one whose age was beyond university education (born in 1934-1938).

Three arguments mitigate this concern though. First, if the 1961 reforms were correlated at the district level with the 1951-1953 reform intensity, one should observe an effect among the cohorts who aged 6 to 10 and 11 to 15 in 1953 (born in 1938-1947), relative to those who aged 16 to 19 in 1953 (born in 19341937). The findings of Table IV do not lend support to this claim though, which is actually not surprising given that the 1961 reforms' effects on these cohorts are conditional on having enrolled in a secondary school or a university. Second, applying the same logic it seems unlikely that the 1961 reforms may account for the observed effect on the treated cohort (born in 1948-1953) because these reforms could have increased this cohort's demand for schooling only among those who were already enrolled in a primary school. Third, I attempted to control for the intensity of the 1961 reforms by three measures, (a) the distance of each district's chef-lieu to the nearest public university in 1959/60, (b) the number of secondary schools per 1,000 male 
children who aged 5 to 19 years in each province in 1959/60, and (c) the logarithm of the number of males who work in administrative and social services (including government employees) in each district in the 1947 population census. The results are shown in Table C.6 and are qualitatively similar to those in Table IV suggesting that the effect on the treated cohort is not primarily driven by these reforms. ${ }^{18}$

This is not to say, however, that the 1961 reforms had no effect. For one thing, their effects may have been uncorrelated with the intensity of the 1951-1953 reform. For another, their effects may have been large among the cohort that was born in 1955-1961, i.e. after the 1951-1953 reform treated cohort. Third, their effects may have operated at the intensive margin among those who were enrolled in schools to begin with.

Besides these two reforms, there were a number of educational reforms that took place in 1944-1949 before the unification of the educational system in 1951-1953 such as (a) the abolition of tuition fees in public primary schools in 1944, (b) the allowance of elementary schools' graduates to sit for the end-of-primaryschool examination in 1945, (c) the abolition of tuition fees in public secondary schools in 1950, and (d) the almost-complete unification of the curricula of public primary schools and public kuttabs in 1948/49. However, reforms (a), (b), and (c) cannot explain the findings because they affected the older cohorts and not the treated one. Furthermore, the cohort that was poised to benefit from reform (d) aged 0 to 5 in 1948 (born in 1943-1948), whereas the cohort that was too old to benefit from it is the one that was beyond primary/elementary schooling in 1948 (born in 1933-1937). As Table IV indicates though, there are no significant differences in outcomes between these two cohorts.

Relatedly, the 1951-1953 reform also increased compulsory schooling in primary schools from 4 to 6 years. Although this may partially account for the improved outcomes of the treated cohort, and is thus impossible to rule out, the fact that it only affects in principle those enrolled (or about to enroll) in primary schools implies that its effect is conditional on transforming elementary schools to primary schools.

Apart from the public reforms in education, there were other reforms that may have affected economic development more generally. Although I was unable to find historical evidence on a national public

\footnotetext{
${ }^{18}$ I also estimated this regression among rural-born and urban-born individuals separately and I obtained similar results to those reported in Table C.3 (results available upon request).
} 
health program during the period, I controlled for health characteristics in each district in 1951/52 and that did not affect the results. One could also suspect that the improved irrigation and electrification of rural Egypt, because of the construction of the Aswan High Dam, might explain the findings. Yet, since the dam was completed in 1970 by the time that the treated cohort had already finished schooling, it cannot explain the improvement in educational attainment among this cohort.

\section{Conclusion}

Employing several novel data sources from Egypt, one of the largest Middle Eastern countries, I examined the impact of the expansion of public mass modern education in 1951-1953, which resulted from the transformation of traditional elementary schools (kuttabs) into public modern primary schools, on the long-standing Christian-Muslim educational and occupational differences, which were in favor of Christians. The results are mixed. I first documented that there was a considerable convergence in educational and occupational attainment between the two groups starting from the mid-twentieth century. I then found that the 1951-1953 reform had a positive and statistically significant impact on Muslims' educational and occupational attainment but had no statistically significant impact on Christians. Nevertheless, its impacts on the Christian-Muslim educational and occupational differentials are imprecisely measured and statistically insignificant. I interpret the findings as a result of the Christian-Muslim differences in students' schooling choices prior to 1951, where most Christian students were already enrolled in modern schools, whereas most Muslim students were enrolled in kuttabs.

The relative success of the 1951-1953 reform in improving Muslims' human capital outcomes is remarkable from a historical perspective given the religion-neutral non-discriminatory nature of the reform. Indeed, some reflection on the long-term history of the phenomenon may be helpful here in order to appreciate the impact of the reform. The Christian-Muslim socioeconomic gap in Egypt persisted since the Middle Ages and up to the early nineteenth century because of certain institutions, such as guilds and religious schools, which made occupations largely hereditary within each religious group. Although Egypt embarked on a state-led modernization program under Muhammad Ali Pasha (1805-1848) in which public modern schools were first introduced to Egypt, those schools remained limited to a tiny Muslim elite, whereas the 
widespread religious schools (kuttabs) remained to be the sole educational choice among the Muslim masses. Interestingly however, a considerable share of Christian students shifted to modern schools starting from the mid-nineteenth century, way ahead of Muslims. Based on the newly digitized 1848 and 1868 Egyptian census samples (Saleh, 2013 and 2015), I find that in 1848, almost all Christian and Muslim students were enrolled in kuttabs. By 1868, however, 40 percent of Christian students enrolled in modern schools, all private, compared

to only 4 percent among Muslim students, most of them were in public schools. By contrast, the more populist 1951-1953 reform was relatively more successful in improving Muslims' human capital, because it transformed kuttabs, which did not qualify their graduates to secondary schools or university education, into upward mobility devices leading students up to white-collar jobs, hence making enrollment in the transformed kuttabs a much more attractive investment for the Muslim masses.

Despite this positive impact, it must be noted that the article did not analyze the drop in quality of public modern education that presumably occurred because of the 1951-1953 reform. In fact, the curriculum of public kuttabs was almost the same as public modern primary schools by 1948/49, and so the unification of the two systems only meant omitting the foreign language requirement from public modern primary schools, and allowing students to advance throughout their primary schooling years even if they fail end-of-year examinations. Quality may have also dropped in kuttabs because of the post-reform higher enrollment rates, larger class sizes, and the lack of well-trained teachers. I would argue, however, that evaluating the 1951-1953 reform should consider the relevant counterfactual which is the situation of the Muslim masses before 1951: Is it better to provide some schooling, regardless of its content, than nothing at all to the masses?

\section{References}

Assaad, Ragui. "The Effects of Public Sector Hiring and Compensation Policies on the Egyptian Labor Market." World Bank Economic Review 11, no. 1 (1997): 85-118.

- "The Structure and Evolution of Employment in Jordan." In The Jordanian Labour Market in the New Millennium, 1-38. Oxford: Oxford University Press, 2014.

Barro, Robert J. and Rachel M. McCleary. "Religion and Economic Growth across Countries." American Sociological Review 68, no. 5 (2003): 760-81.

Becker, Sascha O. and Ludger Woessmann. "Was Weber Wrong? A Human Capital Theory of Protestant Economic History." Quarterly Journal of Economics 124, no. 2 (2009): 531-96.

Boktor, Amir. School and Society in the Valley of the Nile. Cairo: Elias' Modern Press, 1936. 
. The Development and Expansion of Education in the United Arab Republic. Cairo: The American University in Cairo Press, 1963.

Boppart, Timo, Josef Falkinger, Volker Grossmann, Ulrich Woitek, and Gabriela Wüthrich. "Qualifying Religion: The Role of Plural Identities for Educational Production." Institute for Empirical Research in Economics University of Zurich Working Paper No. 360, 2008.

Borooah, Vani K. and Sriya Iyer. "Vidya, Veda, and Varna: The influence of religion and caste on education in rural India." Journal of Development Studies 41, no. 8 (2005): 1369- 1404.

Centre d'Etudes et de Documentation Economiques, Juridiques, et Sociales (CEDEJ). Century Census CDROM: Egypt 1882- 1996. Cairo: CEDEJ, 2003.

Chaudhary, Latika and Jared Rubin. "Reading, Writing, and Religion: Institutions and Human Capital Formation." Journal of Compar/ative Economics 39, no. 1 (2011): 17-33.

Cochran, Judith. Education in Egypt. London: Croom Helm (1986).

Courbage, Youssef and Philippe Fargues. Christians and Jews under Islam. Translated by Judy Mabro. LondonNew York: I. B. Tauris Publishers, 1997.

Cox, Donald and Emmanuel Jimenez. "The Relative Effectiveness of Private and Public Schools: Evidence from Two Developing Countries." Journal of Development Economics 34, no. 1 (1991): 99-121.

Duflo, Esther. "Schooling and Labor Market Consequences of School Construction in Indonesia: Evidence from an Unusual Policy Experiment." American Economic Review 91, no. 4 (2001): 795-813.

Gellner, Ernest. Nations and Nationalism. Oxford: Blackwell, 1983.

Glewwe, Paul. "Schools and Skills in Developing Countries: Education Policies and Socioeconomic Outcomes." Journal of Economic Literature 40, no. 2 (2002): 436-482.

Goldin, Claudia and Lawrence F. Katz. "Mass Secondary Schooling and the State: The Role of State Compulsion in the High School Movement." NBER Working Paper No. 10075. Cambridge, MA: National Bureau of Economic Research, November 2003.

-. "Why the United States Led in Education: Lessons from Secondary School Expansion, 1910 to 1940." In Human Capital and Institutions: A Long Run View, edited by D. Eltis, F. Lewis, and K. Sokoloff, 14378. New York: Cambridge University Press, 2009.

Guiso, Luigi, Paola Sapienzad and Luigi Zingales. "People's Opium? Religion and Economic Attitudes." Journal of Monetary Economics 50 (2003): 225-82.

Hanushek, Eric A. and Ludger Woessmann. "The Role of School Improvement in Economic Development." NBER Working Paper No. 12832. Cambridge, MA: National Bureau of Economic Research, January 2007.

Harby, Mohammed Khayri and El-Sayyed Mohammed El-Azzawi. Education in Egypt (U.A.R) in the 20th Century. Cairo: Ministry of Education: Education Documentation Centre of U.A.R., 1960.

Heyworth-Dunne, James. An Introduction to the History of Education in Modern Egypt. London: Luzac \& Co, 1938.

Issawi, Charles. "The Transformation of the Position of the Millets in the Nineteenth Century." In The Arab World's Legacy, authored by Charles Issawi, 199-230. Princeton, NJ: Darwin Press, 1981.

Kingdon, Geeta. "The Quality and Efficiency of Private and Public Education: A Case-Study of Urban India." Oxford Bulletin of Economics and Statistics 58, no. 1 (1996): 57-82.

La Porta, Rafael, Florencio Lopez-de-Silanes, Andrei Shleifer and Robert W. Vishny. "Trust in Large Organizations." American Economic Review 87, no. 2 (1997): 333-8.

Matthews, Roderic D. and Matta Akrawi. Education in Arab Countries of the Near East. Washington D.C.: The American Council of Education, 1949. 
Ministère des Finances et de l'Economie. Annuaire Statistique 1949-1950 et 1950-1951. Cairo: Imprimerie Nationale, 1953.

Statistique Scolaire. Cairo: Imprimerie Nationale. Years: 1906/07, 1907/08, 1912/1913, 1921/22, 1924/25, 1927/28, 1930/31, 1933/34, 1936/37, 1939/40, 1942/43, 1945/46, 1948/49, 1959/60, and $1969 / 70$.

Pritchett, Lant. "Where Has All the Education Gone?” World Bank Economic Review 15, no. 3 (2001): 367-91.

Richards, Alan. "Higher Education in Egypt." Policy Research Working Paper 862. Washington, D.C.: Population and Human Resources Department, World Bank, 1992.

Ringer, Fritz K. Education and Society in Modern Europe. Bloomington: Indiana University Press, 1979.

Salama, Girgis. Tarikh al-Ta'lim al-ajnabi fi misr fil qarnayn al-tasi' 'ashar wal 'ishreen (History of Foreign Education in Egypt in the Nineteenth and Twentieth Centuries). Cairo: Supreme Council for Art, Literature, and Social Sciences, 1963.

Saleh, Mohamed. "A Pre-Colonial Population Brought to Light: Digitization of the Nineteenth Century Egyptian Censuses," Historical Methods: A Journal of Quantitative and Interdisciplinary History, 46.1 (2013), 5-18.

."The Reluctant Transformation: State Industrialization, Religion, and Human Capital in NineteenthCentury Egypt." Journal of Economic History 75, no. 1 (2015): 65-94.

Smith, Anthony D. Nationalism and Modernism. London and New York: Routledge, 2003.

Somel, Selçuk Akşin. The Modernization of Public Education in the Ottoman Empire, 1839-1908: Islamization, Autocracy and Discipline. Leiden: Brill, 2001.

Szyliowicz, Joseph S. Education and Modernization in the Middle East. Ithaca: Cornell University Press, 1973.

Tagher, Jacques. Christians in Muslim Egypt: A Historical Study of the Relations between Copts and Muslims from 640 to 1922. Altenberge: OrosVerlage, 1998 [1951].

Weber, Eugène. Peasants into Frenchmen: The Modernization of Rural France, 1870-1914. London: Chatto and Windus, 1976.

Yuchtman, Noam. "Teaching to the Tests: An Economic Analysis of Traditional and Modern Education in Late Imperial and Republican China.” Unpublished Manuscript, 2010. 
Table I. Summary Statistics

\begin{tabular}{|c|c|c|c|}
\hline & \multicolumn{2}{|c|}{ Individual-Level Statistics } & \multirow{2}{*}{$\begin{array}{l}\text { District-Level } \\
\text { Statistics }\end{array}$} \\
\hline & Christians & Muslims & \\
\hline \multirow[t]{2}{*}{ Years of Schooling } & 7.19 & 4.73 & \\
\hline & $(6.38)$ & $(5.80)$ & \\
\hline \multirow[t]{2}{*}{ White-Collar Dummy } & 0.43 & 0.25 & \\
\hline & $(0.50)$ & $(0.43)$ & \\
\hline \multirow{2}{*}{$\begin{array}{l}\text { Kuttabs' share in total number of schools in } \\
1951 / 52\end{array}$} & 0.67 & 0.76 & 0.76 \\
\hline & $(0.24)$ & $(0.23)$ & $(0.23)$ \\
\hline \multirow{2}{*}{$\begin{array}{l}\text { Kuttabs' share in total number of male students } \\
\text { enrolled in schools in } 1951 / 52\end{array}$} & 0.51 & 0.60 & 0.62 \\
\hline & $(0.28)$ & $(0.26)$ & $(0.26)$ \\
\hline \multirow[t]{2}{*}{ Kuttabs per 1,000 children in $1951 / 52$} & 1.47 & 1.50 & 1.59 \\
\hline & $(0.54)$ & $(0.62)$ & $(1.03)$ \\
\hline \multirow[t]{2}{*}{ Schools per 1,000 children in $1951 / 52$} & 0.89 & 0.61 & 0.74 \\
\hline & $(0.83)$ & $(0.74)$ & $(1.85)$ \\
\hline \multirow{4}{*}{$\begin{array}{l}\text { Fatalities and maladies from infectious diseases } \\
\text { per } 1,000 \text { population in } 1951 / 52 \\
\text { Hospital beds per } 1,000 \text { population in } 1951 / 52\end{array}$} & 4.76 & 4.33 & 5.77 \\
\hline & $(5.24)$ & $(5.44)$ & $(9.50)$ \\
\hline & 0.34 & 0.37 & 0.34 \\
\hline & $(0.48)$ & $(0.51)$ & $(0.56)$ \\
\hline \multirow{2}{*}{$\begin{array}{l}\mathrm{N} \text { (Full sample) } \\
\mathrm{N} \text { (Workers' sample) }\end{array}$} & 29391 & 397410 & 151 \\
\hline & 27291 & 365229 & 151 \\
\hline
\end{tabular}

Source: Egypt's 1986 10-percent individual-level population census sample merged with district-level data on schools and health characteristics from the Annuaire Statistique 1949-1950 et 1950-1951 (1953, pp. 144-77, 260-71). The sample is restricted to Egyptian Christian and Muslim males who were born in Egypt between 1934 and 1953 (aged 0-19 in 1953), with non-missing values on age, religion, district of birth, and education.

Note: Standard deviations are in parentheses.

\section{Table II. Impact of Reform on Educational and Occupational Attainment by Religion: Experiment of Interest}

\begin{tabular}{|c|c|c|c|c|c|c|}
\hline & $\begin{array}{c}\text { (1) } \\
\text { Years of } \\
\text { schooling - } \\
\text { full sample }\end{array}$ & $\begin{array}{c}(2) \\
\text { Years of } \\
\text { schooling - } \\
\text { workers' } \\
\text { sample }\end{array}$ & $\begin{array}{c}\text { (3) } \\
\text { White- } \\
\text { collar } \\
\text { dummy - } \\
\text { workers' } \\
\text { sample } \\
\end{array}$ & $\begin{array}{c}\text { (4) } \\
\text { Years of } \\
\text { schooling - } \\
\text { full sample }\end{array}$ & $\begin{array}{c}(5) \\
\text { Years of } \\
\text { schooling - } \\
\text { workers' } \\
\text { sample }\end{array}$ & $\begin{array}{c}\text { (6) } \\
\text { White- } \\
\text { collar } \\
\text { dummy - } \\
\text { workers' } \\
\text { sample }\end{array}$ \\
\hline Kuttabs' share in $1951 / 52 *$ Aged $0-5$ in & $0.512^{* * *}$ & $0.596^{* * *}$ & $0.099^{* * *}$ & $0.366^{* *}$ & $0.517^{* * *}$ & $0.083^{* * *}$ \\
\hline $1953\left(\delta_{1}\right)$ & $(0.142)$ & $(0.149)$ & $(0.013)$ & $(0.160)$ & $(0.173)$ & $(0.015)$ \\
\hline Christian * Kuttabs' share in $1951 / 52 *$ & -0.136 & 0.197 & -0.016 & -0.599 & -0.173 & -0.043 \\
\hline Aged $0-5$ in $1953\left(\delta_{2}\right)$ & $(0.497)$ & $(0.499)$ & $(0.042)$ & $(0.587)$ & $(0.595)$ & $(0.052)$ \\
\hline Christian & Yes & Yes & Yes & Yes & Yes & Yes \\
\hline Christian * Year of birth FE? & Yes & Yes & Yes & Yes & Yes & Yes \\
\hline Year of birth FE? & Yes & Yes & Yes & Yes & Yes & Yes \\
\hline Christian * District of birth FE? & Yes & Yes & Yes & Yes & Yes & Yes \\
\hline District of birth FE? & Yes & Yes & Yes & Yes & Yes & Yes \\
\hline $\begin{array}{l}\text { Baseline district's health characteristics * } \\
\text { Aged } 0-5 \text { in } 1953 \text { ? }\end{array}$ & No & No & No & Yes & Yes & Yes \\
\hline $\begin{array}{l}\text { Christian * Baseline district's health } \\
\text { characteristics * Aged 0-5 in 1953? }\end{array}$ & No & No & No & Yes & Yes & Yes \\
\hline P-value $\left(H_{0}: \delta_{1}+\delta_{2}=0\right)$ & 0.471 & 0.116 & 0.049 & 0.702 & 0.567 & 0.429 \\
\hline Number of Districts & 151 & 151 & 151 & 151 & 151 & 151 \\
\hline Observations & 256253 & 236986 & 236986 & 256253 & 236986 & 236986 \\
\hline Adjusted $R^{2}$ & 0.148 & 0.153 & 0.089 & 0.148 & 0.153 & 0.089 \\
\hline
\end{tabular}


Source: Egypt's 1986 10-percent individual-level population census sample merged with district-level data on schools and health characteristics from the Annuaire Statistique 1949-1950 et 1950-1951 (1953, pp. 144-77, 260-71). The sample is restricted to Egyptian Christian and Muslim males who were born in Egypt in 1938-1942 or 1948-1953 (aged 11-15 or 05 in 1953), with non-missing values on age, religion, district of birth, and education.

Notes: ${ }^{*} \mathrm{p}<0.10,{ }^{* *} \mathrm{p}<0.05,{ }^{* * *} \mathrm{p}<0.01$. Standard errors clustered at the district of birth level are in parentheses. Baseline district's health characteristics include (i) the number of fatalities and maladies due to infectious diseases per 1,000 individuals in 1951/52 and (ii) the number of hospital beds per 1,000 individuals in 1951/52.

\section{Table III. Placebo Test of the Impact of the Reform}

\begin{tabular}{|c|c|c|c|c|c|c|}
\hline & $\begin{array}{c}(1) \\
\text { Years of } \\
\text { schooling - } \\
\text { full sample }\end{array}$ & $\begin{array}{c}(2) \\
\text { Years of } \\
\text { schooling - } \\
\text { workers' } \\
\text { sample }\end{array}$ & $\begin{array}{c}(3) \\
\text { White- } \\
\text { collar } \\
\text { dummy - } \\
\text { workers' } \\
\text { sample }\end{array}$ & $\begin{array}{c}\text { (4) } \\
\text { Years of } \\
\text { schooling - } \\
\text { full sample }\end{array}$ & $\begin{array}{c}(5) \\
\text { Years of } \\
\text { schooling - } \\
\text { workers' } \\
\text { sample }\end{array}$ & $\begin{array}{c}\text { (6) } \\
\text { White- } \\
\text { collar } \\
\text { dummy - } \\
\text { workers' } \\
\text { sample }\end{array}$ \\
\hline Kuttabs' share in 1951/52* Aged 11-15 & -0.114 & -0.082 & 0.004 & -0.084 & -0.130 & -0.007 \\
\hline in $1953\left(\delta_{1}\right)$ & $(0.175)$ & $(0.184)$ & $(0.017)$ & $(0.201)$ & $(0.211)$ & $(0.020)$ \\
\hline Christian * Kuttabs' share in $1951 / 52 *$ & 0.615 & 0.642 & $0.075^{*}$ & 0.716 & 0.821 & $0.105^{*}$ \\
\hline Aged $11-15$ in $1953\left(\delta_{2}\right)$ & $(0.563)$ & $(0.590)$ & $(0.044)$ & $(0.796)$ & $(0.810)$ & $(0.060)$ \\
\hline Christian & Yes & Yes & Yes & Yes & Yes & Yes \\
\hline Christian * Year of birth FE? & Yes & Yes & Yes & Yes & Yes & Yes \\
\hline Year of birth FE? & Yes & Yes & Yes & Yes & Yes & Yes \\
\hline Christian * District of birth FE? & Yes & Yes & Yes & Yes & Yes & Yes \\
\hline District of birth FE? & Yes & Yes & Yes & Yes & Yes & Yes \\
\hline $\begin{array}{l}\text { Baseline district's health characteristics * } \\
\text { Aged } 11-15 \text { in } 1953 ?\end{array}$ & No & No & No & Yes & Yes & Yes \\
\hline $\begin{array}{l}\text { Christian * Baseline health district's } \\
\text { characteristics * Aged 11-15 in 1953? }\end{array}$ & No & No & No & Yes & Yes & Yes \\
\hline P-value $\left(H_{0}: \delta_{1}+\delta_{2}=0\right)$ & 0.346 & 0.313 & 0.065 & 0.387 & 0.352 & 0.073 \\
\hline Number of Districts & 150 & 150 & 150 & 150 & 150 & 150 \\
\hline Observations & 157414 & 142623 & 142623 & 157414 & 142623 & 142623 \\
\hline Adjusted $R^{2}$ & 0.163 & 0.173 & 0.115 & 0.163 & 0.173 & 0.115 \\
\hline
\end{tabular}

Source: Egypt's 1986 10-percent individual-level population census sample merged with district-level data on schools and health characteristics from the Annuaire Statistique 1949-1950 et 1950-1951 (1953, pp. 144-77, 260-71). The sample is restricted to Egyptian Christian and Muslim males who were born in Egypt between 1934 and 1942 (aged 11-19 in 1953), with non-missing values on age, religion, district of birth, and education.

Notes: ${ }^{*} \mathrm{p}<0.10,{ }^{* *} \mathrm{p}<0.05,{ }^{* * *} \mathrm{p}<0.01$. Standard errors clustered at the district of birth level are in parentheses. Baseline district's health characteristics include (i) the number of fatalities and maladies due to infectious diseases per 1,000 individuals in 1951/52 and (ii) the number of hospital beds per 1,000 individuals in 1951/52. 
Table IV. Impact of Reform by Religion and Cohort of Birth

\begin{tabular}{|c|c|c|c|c|c|c|}
\hline & $\begin{array}{c}(1) \\
\text { Years of } \\
\text { schooling - } \\
\text { All }\end{array}$ & $\begin{array}{c}(2) \\
\text { Years of } \\
\text { schooling - } \\
\text { Workers }\end{array}$ & $\begin{array}{c}\text { (3) } \\
\text { White- } \\
\text { collar - } \\
\text { Workers }\end{array}$ & $\begin{array}{c}(4) \\
\text { Years of } \\
\text { schooling - } \\
\text { All }\end{array}$ & $\begin{array}{c}(5) \\
\text { Years of } \\
\text { schooling - } \\
\text { Workers }\end{array}$ & $\begin{array}{c}\text { (6) } \\
\text { White- } \\
\text { collar - } \\
\text { Workers }\end{array}$ \\
\hline Kuttabs' share in 1951/52* Aged 11-15 & -0.115 & -0.087 & 0.003 & -0.091 & -0.139 & -0.009 \\
\hline in $1953\left(\delta_{12}\right)$ & $(0.176)$ & $(0.185)$ & $(0.017)$ & $(0.202)$ & $(0.212)$ & $(0.020)$ \\
\hline Kuttabs' share in $1951 / 52 *$ Aged 6-10 in & -0.080 & -0.017 & $0.038^{*}$ & -0.136 & -0.073 & 0.012 \\
\hline $1953\left(\delta_{13}\right)$ & $(0.221)$ & $(0.228)$ & $(0.020)$ & $(0.274)$ & $(0.279)$ & $(0.024)$ \\
\hline $\begin{array}{l}\text { Kuttabs' share in } 1951 / 52 * \text { Aged } 0-5 \text { in } \\
1953\left(\delta_{14}\right)\end{array}$ & $\begin{array}{l}0.407^{* *} \\
(0.184)\end{array}$ & $\begin{array}{c}0.521^{* * *} \\
(0.197)\end{array}$ & $\begin{array}{l}0.102^{* * *} \\
(0.019)\end{array}$ & $\begin{array}{c}0.275 \\
(0.214)\end{array}$ & $\begin{array}{c}0.377 \\
(0.233)\end{array}$ & $\begin{array}{c}0.075^{* * *} \\
(0.022)\end{array}$ \\
\hline Christian * Kuttabs' share in $1951 / 52 *$ & 0.682 & 0.678 & $0.079^{*}$ & 0.865 & 0.941 & $0.112^{*}$ \\
\hline Aged $11-15$ in $1953\left(\delta_{22}\right)$ & $(0.559)$ & $(0.584)$ & $(0.044)$ & $(0.802)$ & $(0.810)$ & $(0.060)$ \\
\hline Christian * Kuttabs' share in 1951/52* & $0.981^{*}$ & 0.954 & 0.086 & 1.053 & 1.227 & $0.128^{*}$ \\
\hline Aged 6-10 in $1953\left(\delta_{23}\right)$ & $(0.569)$ & $(0.593)$ & $(0.052)$ & $(0.755)$ & $(0.832)$ & $(0.074)$ \\
\hline Christian * Kuttabs' share in $1951 / 52 *$ & 0.583 & 0.902 & 0.066 & 0.263 & 0.769 & 0.073 \\
\hline Aged $0-5$ in $1953\left(\delta_{24}\right)$ & $(0.677)$ & $(0.584)$ & $(0.046)$ & $(0.874)$ & $(0.758)$ & $(0.063)$ \\
\hline Christian & Yes & Yes & Yes & Yes & Yes & Yes \\
\hline Christian * Year of birth FE? & Yes & Yes & Yes & Yes & Yes & Yes \\
\hline Year of birth FE? & Yes & Yes & Yes & Yes & Yes & Yes \\
\hline Christian * District of birth FE? & Yes & Yes & Yes & Yes & Yes & Yes \\
\hline District of birth FE? & Yes & Yes & Yes & Yes & Yes & Yes \\
\hline $\begin{array}{l}\text { Baseline district's health characteristics * } \\
\text { Aged 11-15 in 1953? }\end{array}$ & No & No & No & Yes & Yes & Yes \\
\hline $\begin{array}{l}\text { Baseline district's health characteristics * } \\
\text { Aged 6-10 in 1953? }\end{array}$ & No & No & No & Yes & Yes & Yes \\
\hline $\begin{array}{l}\text { Baseline district's health characteristics * } \\
\text { Aged 0-5 in 1953? }\end{array}$ & No & No & No & Yes & Yes & Yes \\
\hline $\begin{array}{l}\text { Christian * Baseline district's health } \\
\text { characteristics * Aged 11-15 in 1953? }\end{array}$ & No & No & No & Yes & Yes & Yes \\
\hline $\begin{array}{l}\text { Christian * Baseline district's health } \\
\text { characteristics * Aged 6-10 in } 1953 \text { ? }\end{array}$ & No & No & No & Yes & Yes & Yes \\
\hline $\begin{array}{l}\text { Christian * Baseline district's health } \\
\text { characteristics * Aged } 0-5 \text { in } 1953 ?\end{array}$ & No & No & No & Yes & Yes & Yes \\
\hline $\mathrm{P}\left(H_{0}: \delta_{14}-\delta_{12}=0\right)$ & 0.000 & 0.000 & 0.000 & 0.021 & 0.003 & 0.000 \\
\hline $\mathrm{P}\left(H_{0}: \delta_{14}-\delta_{13}=0\right)$ & 0.001 & 0.001 & 0.000 & 0.013 & 0.009 & 0.000 \\
\hline $\mathrm{P}\left(H_{0}: \delta_{14}+\delta_{24}=0\right)$ & 0.148 & 0.016 & 0.001 & 0.530 & 0.117 & 0.025 \\
\hline $\mathrm{P}\left(H_{0}:\left(\delta_{14}+\delta_{24}\right)-\left(\delta_{12}+\delta_{22}\right)=0\right)$ & 0.420 & 0.102 & 0.040 & 0.700 & 0.573 & 0.396 \\
\hline $\mathrm{P}\left(H_{0}:\left(\delta_{14}+\delta_{24}\right)-\left(\delta_{13}+\delta_{23}\right)=0\right)$ & 0.846 & 0.276 & 0.202 & 0.477 & 0.987 & 0.845 \\
\hline $\mathrm{P}\left(H_{0}: \delta_{24}-\delta_{22}=0\right)$ & 0.844 & 0.659 & 0.760 & 0.313 & 0.778 & 0.465 \\
\hline $\mathrm{P}\left(H_{0}: \delta_{24}-\delta_{23}=0\right)$ & 0.368 & 0.904 & 0.604 & 0.118 & 0.362 & 0.206 \\
\hline Number of Districts & 151 & 151 & 151 & 151 & 151 & 151 \\
\hline Observations & 426801 & 392520 & 392520 & 426801 & 392520 & 392520 \\
\hline Adjusted $R^{2}$ & 0.154 & 0.160 & 0.095 & 0.154 & 0.160 & 0.095 \\
\hline
\end{tabular}

Source: Egypt's 1986 10-percent individual-level population census sample merged with district-level data on schools and health characteristics from the Annuaire Statistique 1949-1950 et 1950-1951 (1953, pp. 144-77, 260-71). The sample is restricted to Egyptian Christian and Muslim males who were born in Egypt between 1934 and 1953 (aged 0-19 in 1953), with non-missing values on age, religion, district of birth, and education.

Notes: ${ }^{*} \mathrm{p}<0.10,{ }^{* *} \mathrm{p}<0.05,{ }^{* * *} \mathrm{p}<0.01$. Standard errors clustered at the district of birth level are in parentheses. Baseline district's health characteristics include (i) the number of fatalities and maladies due to infectious diseases per 1,000 individuals in 1951/52 and (ii) the number of hospital beds per 1,000 individuals in 1951/52. 
Figure I. Egypt's Supplies of Kuttabs and Modern Schools per 1,000 Children in 1906-1970

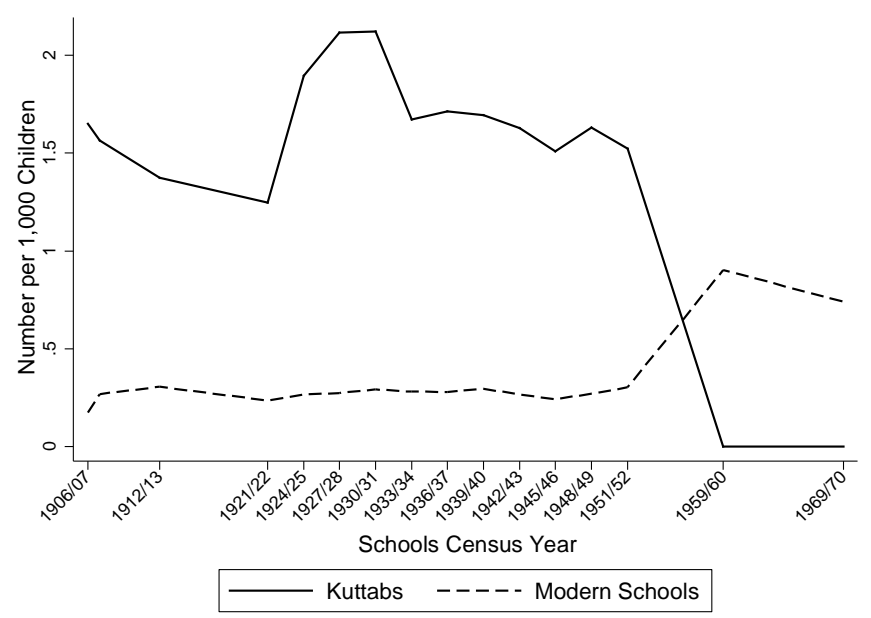

Source: Egypt's school censuses (Statistique Scolaire) from 1906/07 to 1969/70.

Notes: Modern schools include primary and secondary schools and higher education institutions. Numbers are adjusted by Egypt's school-age population that I obtained from the closest population census. Kuttabs are adjusted by the population aged from 5 to 14 years, whereas modern schools are adjusted by the population aged from 5 to 19 years. The only exception is in 1921/22 where I adjusted Kuttabs by the population aged 5 to 19 years, because I could not find information on the population aged 5-14 years in the 1917 population census.

Figure II. Sectoral Composition of Kuttabs and Modern Schools in 1906/07-1951/52
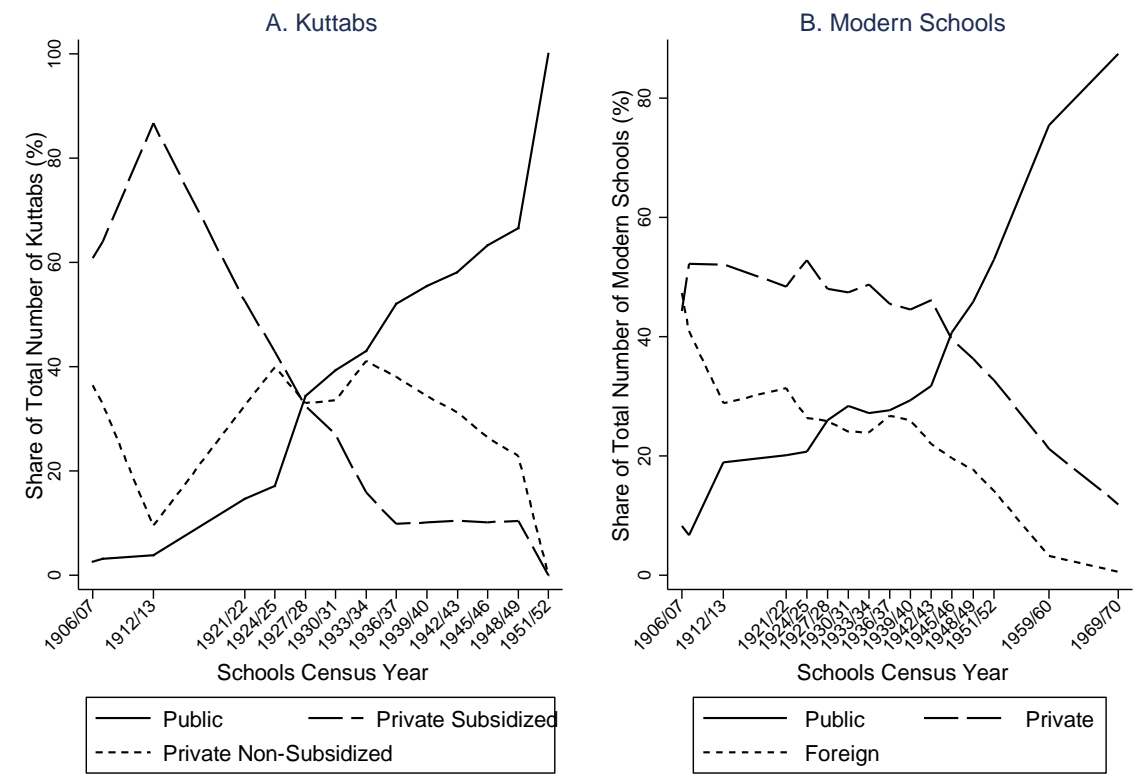

Source: Egypt's school censuses (Statistique Scolaire) from 1906/07 to 1969/70.

Notes: Modern schools include primary and secondary schools and higher education institutions. 
Figure III. Educational and Occupational Attainment by Religion and Cohort of Birth

A. Years of Schooling
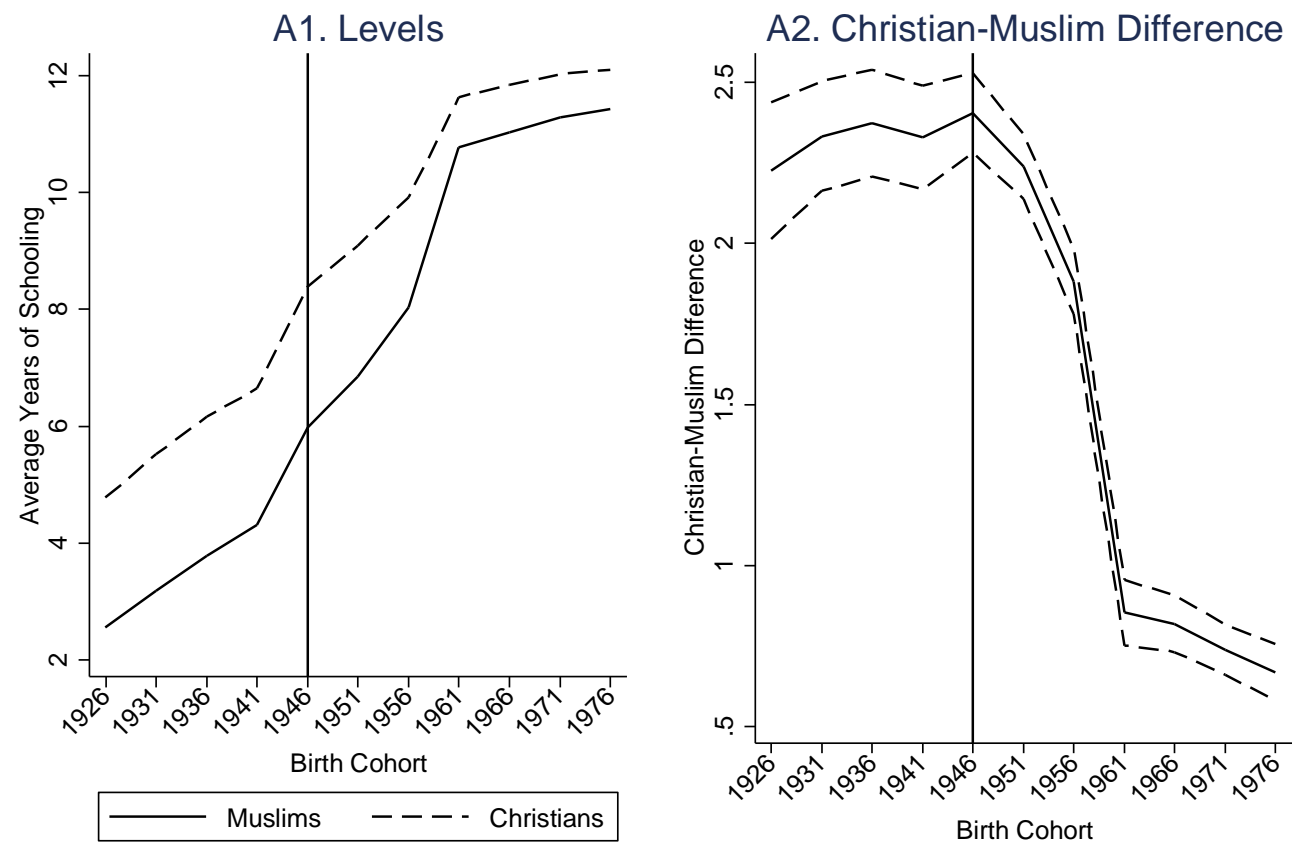

B. \% Literate
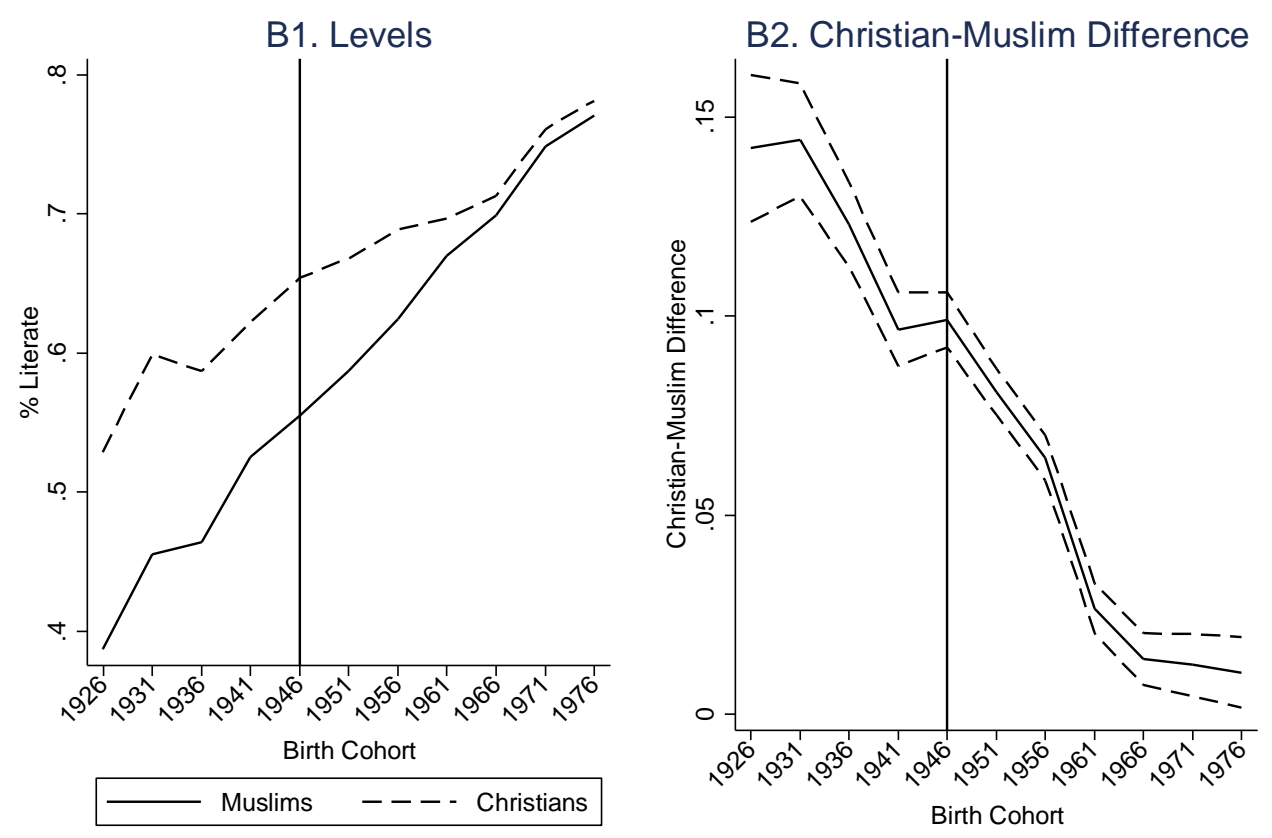


\section{C. \% White-Collar}
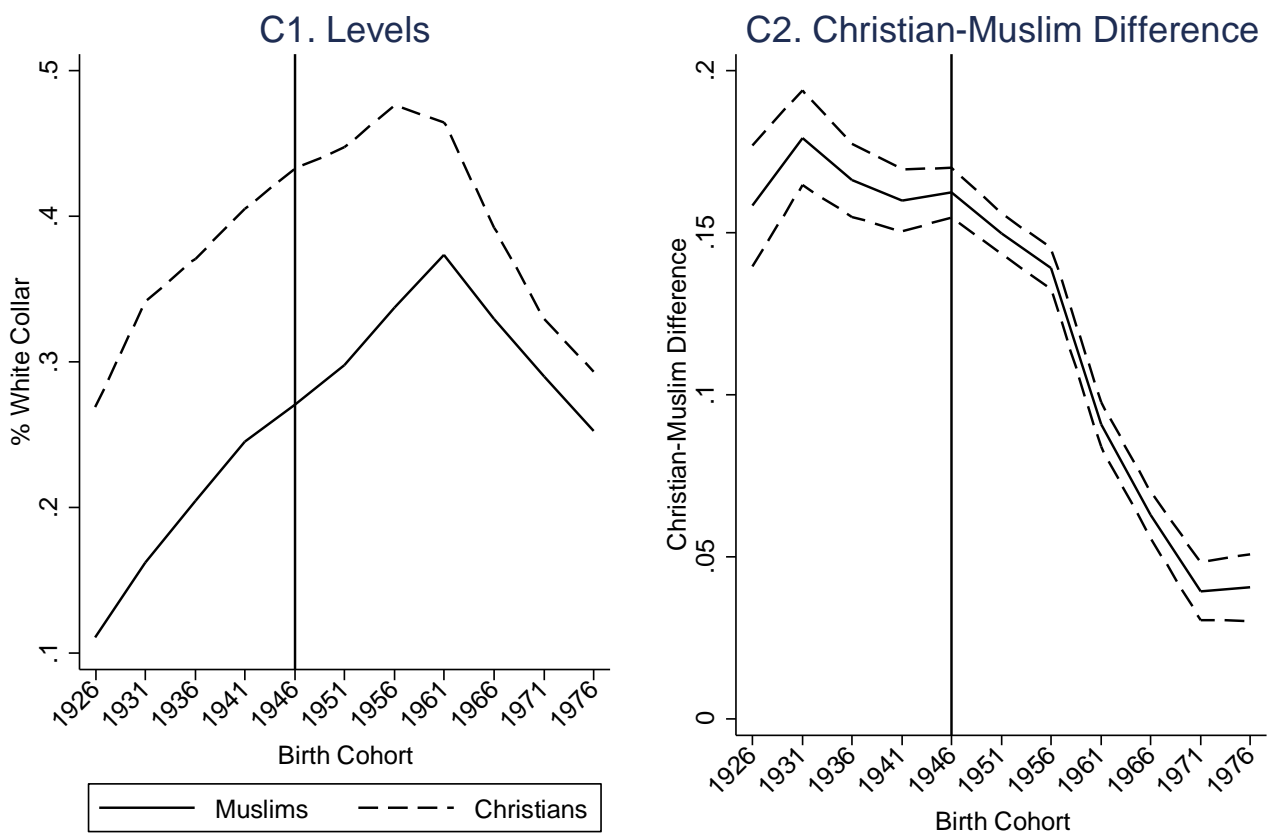

Source: Egypt's pooled 10-percent individual-level population census samples from 1986, 1996, and 2006. The sample is restricted to Egyptian Christian and Muslim males who were born in Egypt and aged between 30 and 60 years in 1986 , 1996, or 2006, with non-missing values on age, religion, province of birth, and education.

Notes: Each year represents a birth cohort. I constructed 5-year window cohorts of birth centered on heap years.

Figure IV. Decennial Marginal Effects of Non-Muslims' Population Share on Mean Educational and Occupational Attainment at the Village/Quarter-Level in 1897-1986

(A) Dependent Variable: Percentage of Males Who Are Able to Read and Write

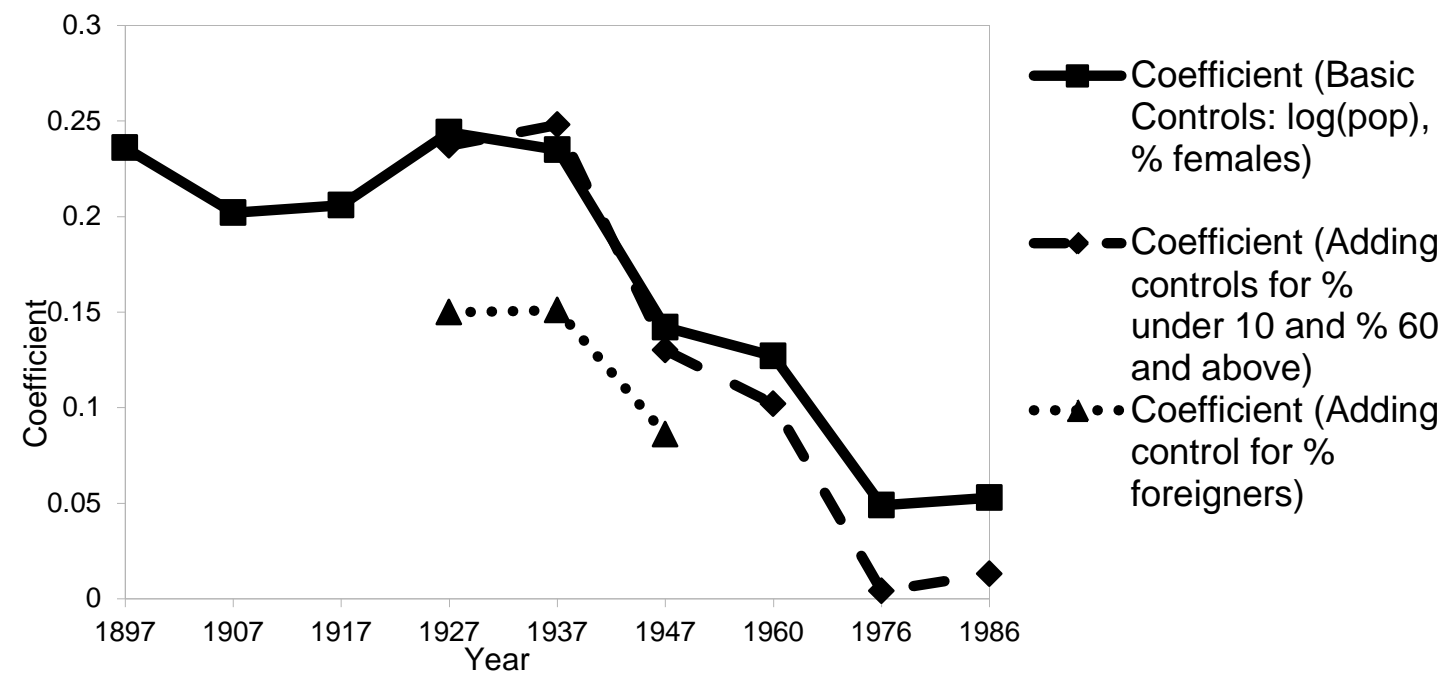


(B) Dependent Variable: Percentage of Males Working in the Non-Agricultural Sector

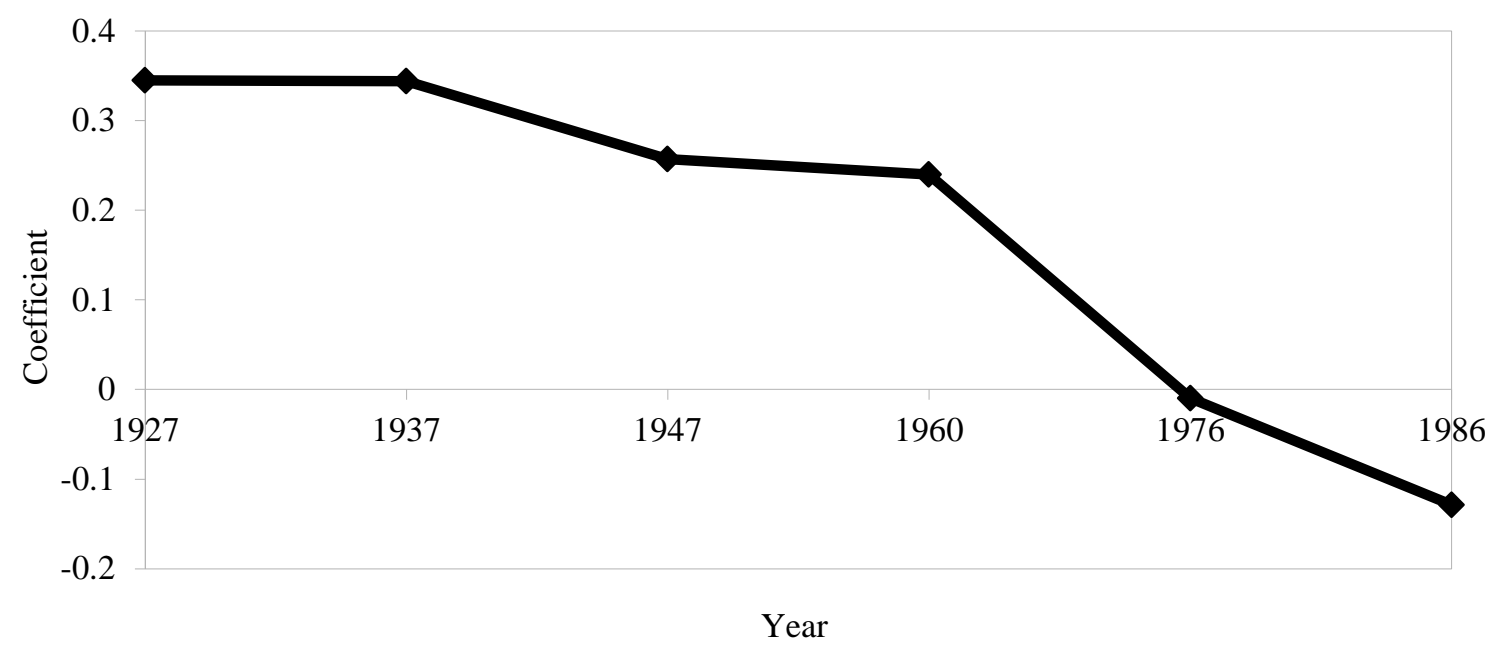

Source: Egypt's decennial village/quarter-level population censuses in 1897-1986 from CEDEJ (2003).

Notes: Panels (A) and (B) depict the decennial estimates of $\gamma_{t}$ from equation (1). Control variables in panel (B) include: $\log$ (population), percentage of females, percentage of population aged below 10, and percentage of population aged 60 and above.

Figure V. Christian and Muslim Student Enrollment Rates in 1907/08-1948/49

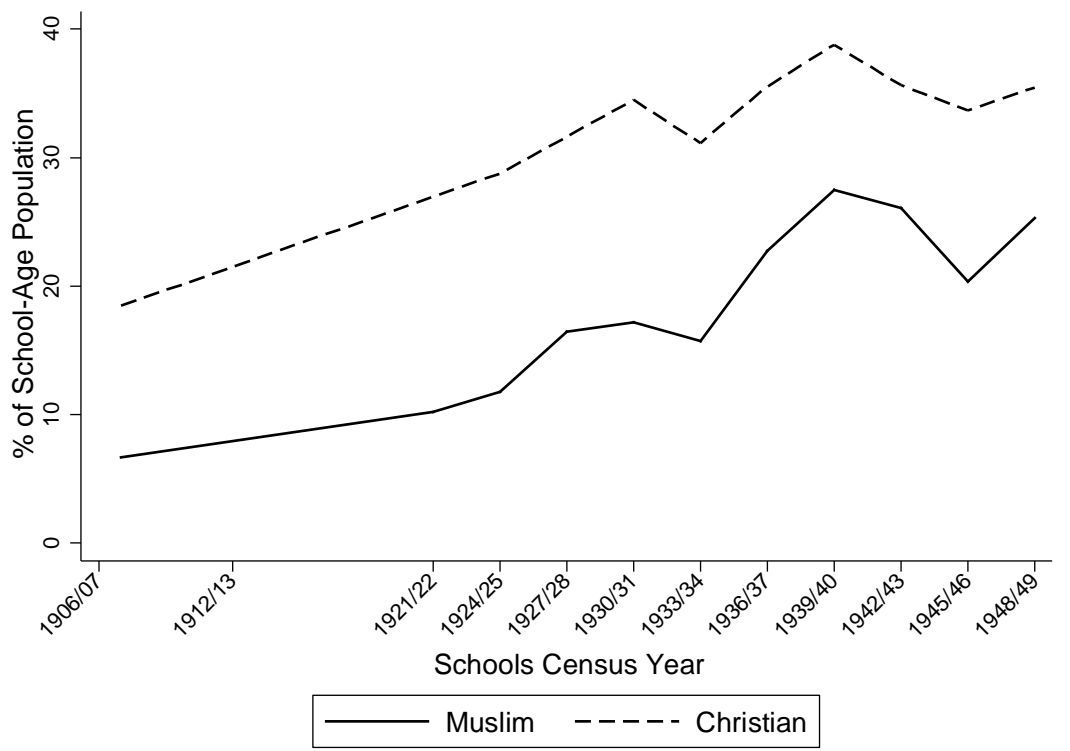

Source: School censuses (Statistique Scolaire) from 1906/07 to 1948/49 and the population censuses in 1907- 1947. Notes: School-age population is the population aged from 5 to 19 years. Christian students in modern schools include both Copts and non-Coptic Christians, while those in kuttabs are only Copts (no information on non-Coptic Christian students in kuttabs). I computed Muslim and Christian school-age population from the closest population census by multiplying the population share of each religious group by the total school-age population. 
Figure VI. Educational Choices of Christian and Muslim Students in 1907/08-1948/49
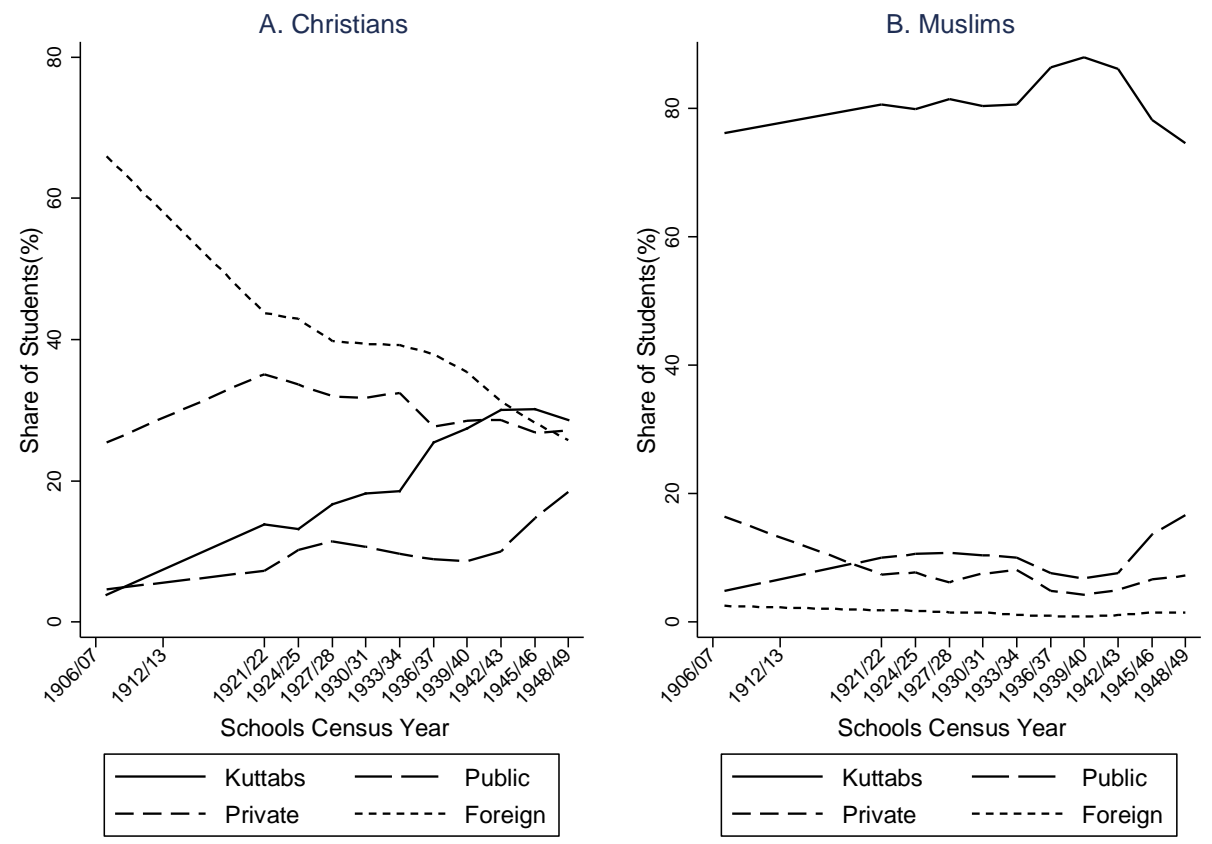

Source: Egypt's school censuses (Statistique Scolaire) from 1907/08 to 1948/49.

Figure VII. Composition of Egyptian Private Modern Schools in 1906/07-1951/52

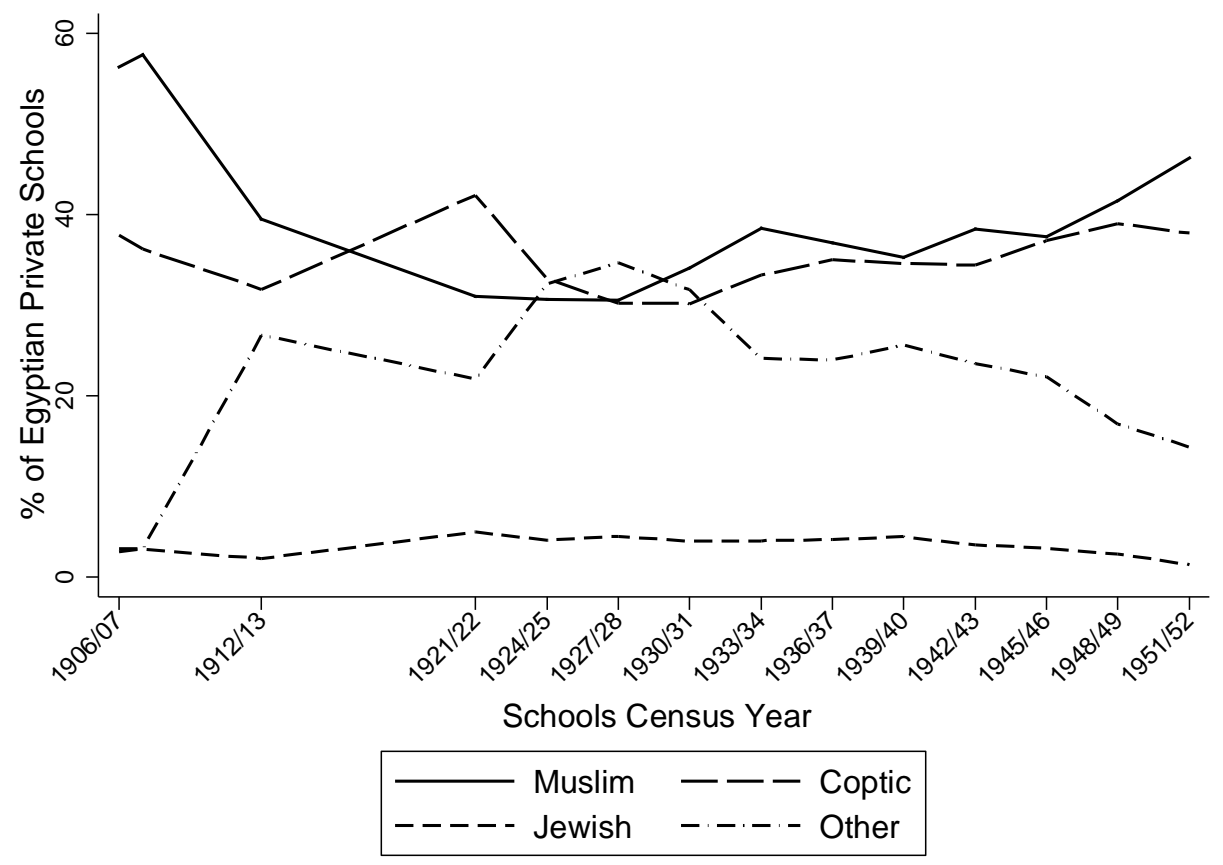

Source: Egypt's school censuses (Statistique Scolaire) from 1906/07 to 1951/52. 